\title{
25. THE LATE NEOGENE OF THE GULF OF MEXICO
}

\author{
Lee A. Smith and John H. Beard, Esso Production Research Company, Houston, Texas
}

\begin{abstract}
The calcareous nannofossils have become important shipboard biostratigraphic tools, but the planktonic foraminifers provide the presently accepted stratigraphic framework for Cenozoic oceanic sediments. The ranges of Late Neogene calcareous nannofossils have not previously been well documented in terms of the planktonic foraminiferal zonation scheme. This multiple discipline effort provides that documentation, at least for the Gulf of Mexico region.

The planktonic foraminiferal zonation scheme of Lamb and Beard (1972) is reviewed and its calibration with land-based stratotypes for the Late Neogene and Quaternary is discussed. Both the foraminiferal zonation and that of Martini (1971), based on calcareous nannofossils, are applied to the same samples from Late Neogene cores recovered from DSDP Holes $85,86,88,89$, 90, 91, 94, and 97, taken in the Gulf of Mexico on Leg 10. Documented also are the overlapping ranges of Globorotalia truncatulinoides and Discoaster brouweri in Calabrian and Emilian equivalents of the Gulf of Mexico-undoubted Early Pleistocene.
\end{abstract}

\section{INTRODUCTION}

The remains of planktonic organisms play an increasingly important role in the dating and correlating of Cretaceous and Cenozoic marine strata. The availability of deep-sea core data has contributed enormously to our understanding of evolutionary trends as well as both the temporal and geographic distributions of ancient plankton. The stimulation of interest in the study of planktonic microfossils by the deep-sea drilling program has, in turn, furnished both the working time stratigraphic tools for the shipboard geological oceanographer and the relative time framework within which the geological history of ocean basins must be interpreted. In making decisions concerning the age of oceanic sediments, however, we must not neglect the accepted points of reference that the classical landbased sections provide for the relative time scale.

In the past, emphasis has been given the planktonic foraminifers with the result that they have become more or less accepted as providing the standard biostratigraphic framework for the Cenozoic. The calcareous nannofossils, however, have become relatively important for rapid shipboard work, and they and the radiolarians provide control where the planktonic foraminiferal assemblages may be lacking-at higher latitudes and in deeper waters. To complete the maximum coverage for the broadest spectrum of facies the dinoflagellates also should be included. The ultimate in biostratigraphy will be achieved through the integrated study of all the major planktonic groups in order to provide sufficient datums in all marine facies. Too little integration has been attempted, much less achieved.

In performing the shipboard work for DSDP Leg 10 in the Gulf of Mexico, Smith and McNeely (this volume), for purposes of communication, attempted to apply the zonation scheme suggested by Blow and Banner (1966) modified by Blow (1969). Difficulties were encountered, especially in Late Neogene sediments. Although at that time unpublished, we actually used, quite successfully, the zonation proposed by Lamb and Beard (1972) for the post-Middle Miocene sections. Since it has now been published, it was decided to demonstrate its applicability in the laboratory study of cores recovered on Leg 10 in the Gulf of Mexico. Beard and Smith have been working together for several years on the integration of planktonic foraminiferal and coccolith biostratigraphy and continued this team effort on the Late Neogene sediments recovered from Holes 85 through 97.

In the present paper, the authors attempt to shed light on the three areas of greatest need in the study of Late Neogene oceanic sediments-zonation, calibration, and multidiscipline integration.

Calibration with standard land-based sections is summarized in some depth in order to provide an understanding of the need for and accuracy of the Late Neogene zonation scheme of Lamb and Beard (1972). The zonation scheme itself is reviewed for the reader not having access to the original publication. Its utility is demonstrated through its application to the interpretation of the sections penetrated on Leg 10. The relationships among the planktonic foraminiferal species and between the planktonic foraminifers and calcareous nannofossil species are documented with their occurrences in the cores recovered from Holes 85,86 , $88,89,91,94$, and 97 in the Gulf of Mexico.

\section{PLANKTONIC SUCCESSION WITHIN STANDARD REFERENCE SECTIONS-ITALY}

\section{General}

A brief account of some standard European marine stages (Figure 1) is essential to understand the measure of 


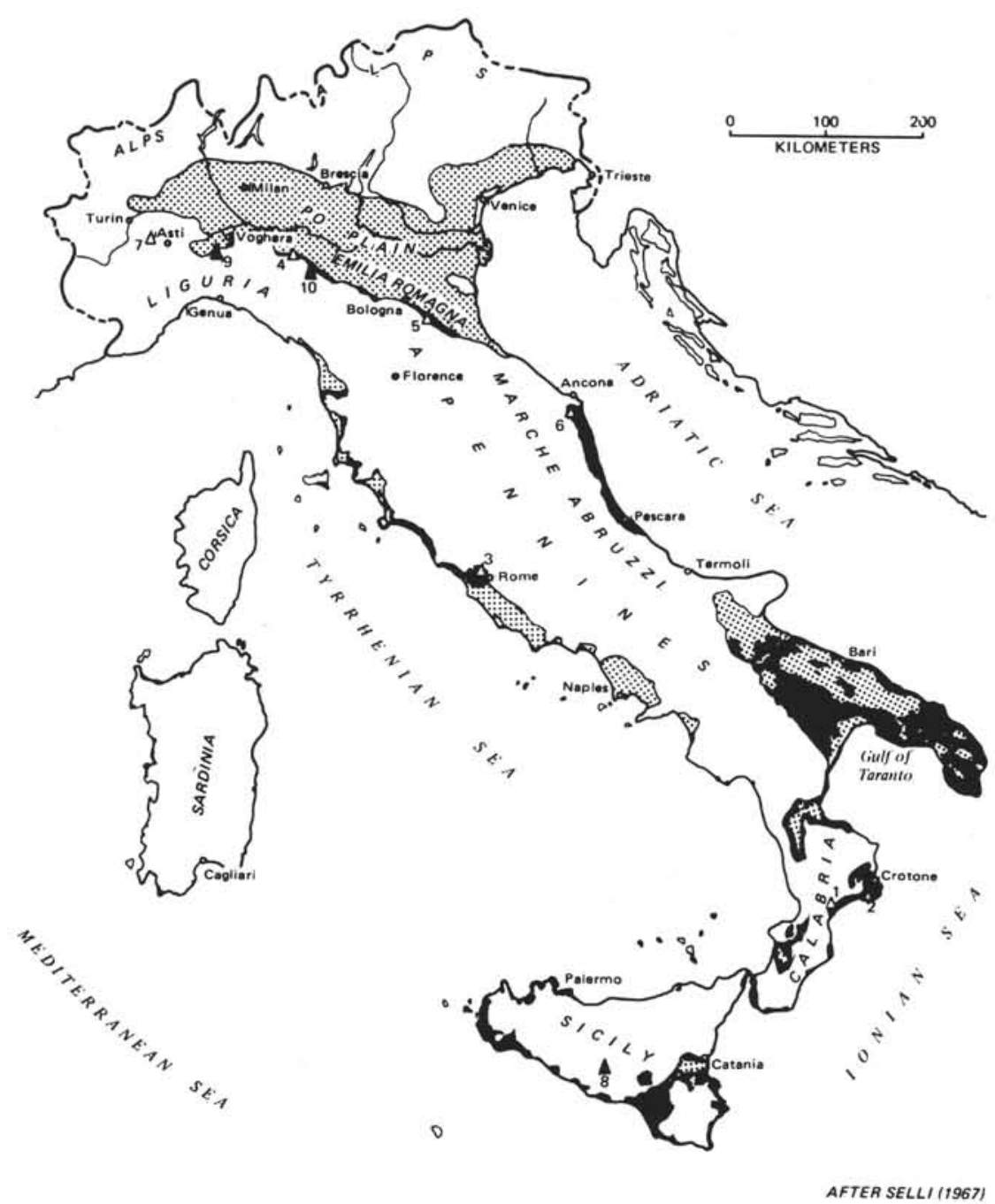

Figure 1. Distribution of marine Pleistocene in Italy, outcropping (black) and covered with more recent continental terrains (dotted). White triangles show localities of important sections for the Pliocene-Pleistocene boundary. Black triangles show important Miocene and Pliocene localities: 1-Santa Maria di Catanzaro ("type" Calabrian); 2-Le Castella ("type" Calabrian); 3-Monte Mario; 4-Castell 'Arquato-Vernasca (type Plaisancian); 5-Santerno; 6-Musone; 7-Villafranca d'Asti (type Villafranchian); 8-Pasquasia-Capodarso (type Messinian); 9-Rio Massapiedi-Castellania (type Tortonian); and 10-Tabiano (type Tabianian).

accuracy that is implied with reference to stage and epoch boundaries in the Caribbean and the Gulf of Mexico. Literature relating to the Italian late Neogene (herein defined as that portion of geologic time from the Middle Miocene-Globorotalia menardii Zone through the Holocene-Globorotalia tumida Zone) sedimentary succession is indeed voluminous and is treated in many languages. Because of their somewhat provincial character, the numerous discussions cannot be fully appreciated, however, by only casual acquaintance with some of the major works. To remedy this, the Committee on Mediterranean Neogene Stratigraphy (CMNS) (1967) at its fourth session in
Bologna published, under the editorial guidance of Raimondo Selli in collaboration with many recognized authorities, a multilanguage rendition in the excursion guidebooks (Number 1 and 2) of some historically important contributions to the understanding of type localities of the Italian Neogene succession. The full texts of the papers presented at the Bologna session are contained in Volume 35 of the Giornale di Geologia. Of special interest is the proposal by Bertolino et al. (1968) of a subdivision of the Italian Neogene based on planktonic foraminifers (Figure 2).

A post-session discussion of the several Neogene planktonic zonal schemes proposed by different authors was 
organized by Hans Bolli and others at Bologna University on May 15-17, 1968. A review of this meeting is given by Cati et al. (1968); the stratigraphic position and correspondence of the Late Miocene and Pliocene planktonic zones are shown in Figure 3.

\section{Tortonian Stage (Late Miocene)}

The Tortonian Stage was proposed by Mayer-Eymar in 1858. The section exposed along the Castellania and Mazzapiedi rivers, chosen as the stratotype by Gianotti (1953), is about 260 meters thick and extends from the Serravalian ("Helvetian") at the bottom to the Messinian at the top. Planktonic foraminifers are abundant and display a characteristic distribution. Cita et al. (1965) recognized in the type Tortonian the "Globorotalia mayeri"/G. lenguaensis Zone (corresponding to the lower part of the section for about 30 meters), the "Globorotalia mayeri"/Globigerina nepenthes Zone (lower middle part), and the Globorotalia menardii/Globigerina nepenthes Zone, which they extend up to the base of an interval they consider as Messinian. This planktonic zonation seemingly follows closely that which Blow (1959) applied in zoning the planktonic sequence within the upper part of the Pozon Formation of Falcon, Venezuela, and which compared in part with and extends upward the Trinidad zonation of Bolli (1957).

Samples were collected from the type Tortonian section along the Castellania and Mazzapiedi rivers by Deryck D. Bayliss and studied by Cita and Blow (1969). They maintained that the Globorotalia siakensis Zone (=Globorotalia mayeri Zone of Cita et al., 1965) is not represented in the section studied and that the lower 35 meters (approximately) of the stratotype Tortonian are referable to the Globorotalia (T.) continuosa Zone (=Zone N.15) of Blow (1969) and to the Globorotalia menardii Zone sensu Bolli (1957), emend. Bolli (1966). They continue by saying that the Globorotalia acostaensis datum (earliest appearance of the species) is about 35 meters above the base of the section. Accordingly, they say that the base of the section falls within the upper limits of the Globorotalia menardii Zone and the upper part within the Globorotalia acostaensis, Globigerina dutertrei, and Globorotalia margaritae zones of Bolli (1966), which equate with Blow's zones N.16 and N.17 (in part).

If the base of the Pliocene is to be designated by the Tabianian Stage, Cita and Blow (1969) saw no need for a concept of a Messinian Stage which, according to them, is partly coeval with the Tortonian Stage. The following discussion of the Messinian Stage should show convincingly that Messinian deposits are mostly younger than those of the Tortonian and that it is highly unlikely that Tortonian and/or Messinian strata fall within the limits of the Tabianian Stage (Globorotalia margaritae Zone).

The base of the Tortonian Stage is, then, no older than late Globorotalia menardii Zone, while the upper limit falls within the range-zone of Globorotalia acostaensis. It seems acceptable to follow the decision of Cita and Blow (1969) to place the Tortonian in the terminal Miocene (with the Messinian) rather than in the middle Miocene as has been the customary practice, but it should not be construed that it is the time equivalent of the Messinian.

For purposes of regional and intercontinental faunal correlation it would be desirable to designate arbitrarily the base of the range-zone of Globorotalia acostaensis as the base of the Tortonian Stage and the onset of the late Miocene. The first appearance of $G$. acostaensis is proving to be an excellent datum for worldwide correlation.

\section{Messinian Stage (Late Miocene)}

The Messinian Stage was proposed by Mayer-Eymar (1868) to include a succession of strata near Messina in northern Sicily. Because of poor exposures and stratigraphical difficulties within this sequence, Selli (1960) designated the Pasquasia-Capodarso section in central Sicily as a neostratotype for this stage. These exposures occur between the towns of Caltanisetta and Enna. Although evaporite deposits commonly enhance recognition of the Messinian throughout Italy, the foraminiferal faunas described by D'Onofrio (1964) do not lend themselves directly to extra-Mediterranean correlation. Sulphur, gypsum, and salt are common constituents of Messinian strata in Italy and are often the sole criteria used to recognize the stage. The planktonic fauna of the early Messinian becomes impoverished upward as the evaporites are approached.

Approximately 170 meters of poorly fossiliferous strata occur in the type section. An uppermost 10 meters of shale, however, are moderately rich in planktonic species. Samples from this interval, collected by geologists of the Esso Production Research Company, contain Sphaeroidinellopsis sphaeroides Lamb, 1969 (=S. seminulina of authors) and Globorotalia acostaensis. In the area to the east of the type locality, between the town of Rossano and the Trionto River, widely exposed Messinian strata are overlain unconformably by Calabrian beds. From the upper portion of these Messinian strata (i.e., within the Gessi Formation) Ogniben (1962) identified a planktonic foraminiferal facies containing Globigerinoides conglobatus, Hastigerina aequilateralis, and Orbulina universa. These species are useful in correlating with the Caribbean and Gulf of Mexico, where they also occur. Italian authors define the upper limit of the Messinian as corresponding closely with the base of the Globorotalia margaritae ( $=G$. hirsuta of authors) Zone (early Pliocene) in both southern and northern Italy.

Tabianian, Plaisancian, and Astian Stages (Early, Middle, and Late Pliocene)

The Pliocene terrains exposed along the southern border of the Apennines, that is, around the towns of Tabiano, Vernasca, and Castell'Arquato, constitute the type Pliocene according to Mayer-Eymar (1868). The Pliocene sequence in the vicinity of Vernasca and Castell'Arquato is about 950 meters thick (Barbieri, 1967) and is represented by three stratigraphic units, which from bottom to top are as follows:

1) Vernasca Sandstone-Thickness, about 85 meters, Tabianian (Early Pliocene).

2) Lower Lugagnano Claystone-Thickness, 170 meters, Tabianian (Early Pliocene).

Upper Lugagrians claystone-Thickness, 280 meters, Plaisancian (Middle to Late Pliocene).

3) Castell'Arquato Sandstone-Thickness, about 140 meters, Astian.

The the east, near the town of Tabiano, the Vernasca Sandstone lies conformably on the Messinian. The maxi- 
L. A. SMITH, J. H. BEARD

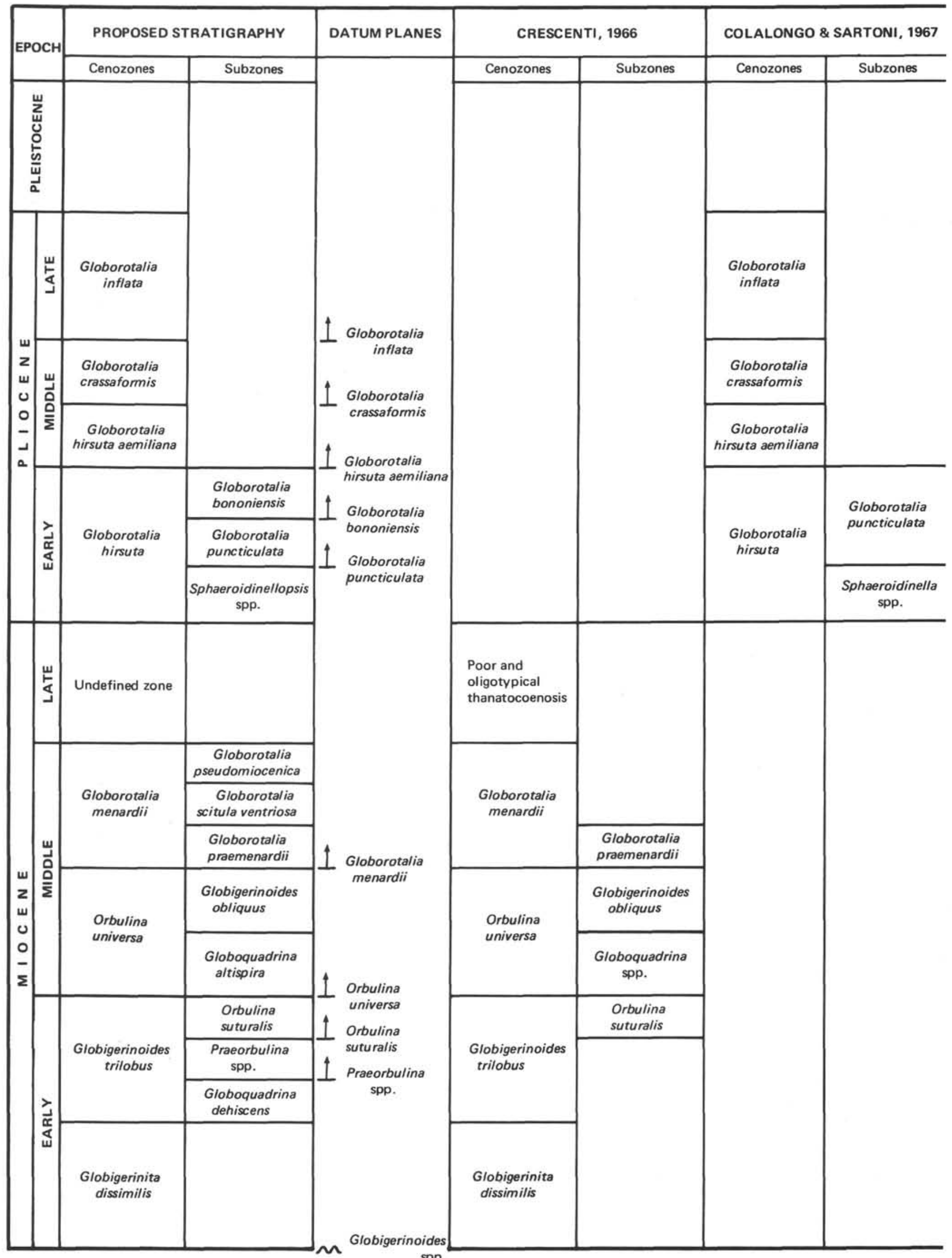

Figure 2. Zonal scheme for the Miocene and Pliocene of the Mediterranean area based on planktonic foraminifers (after Bertolino and et al., 1968). 


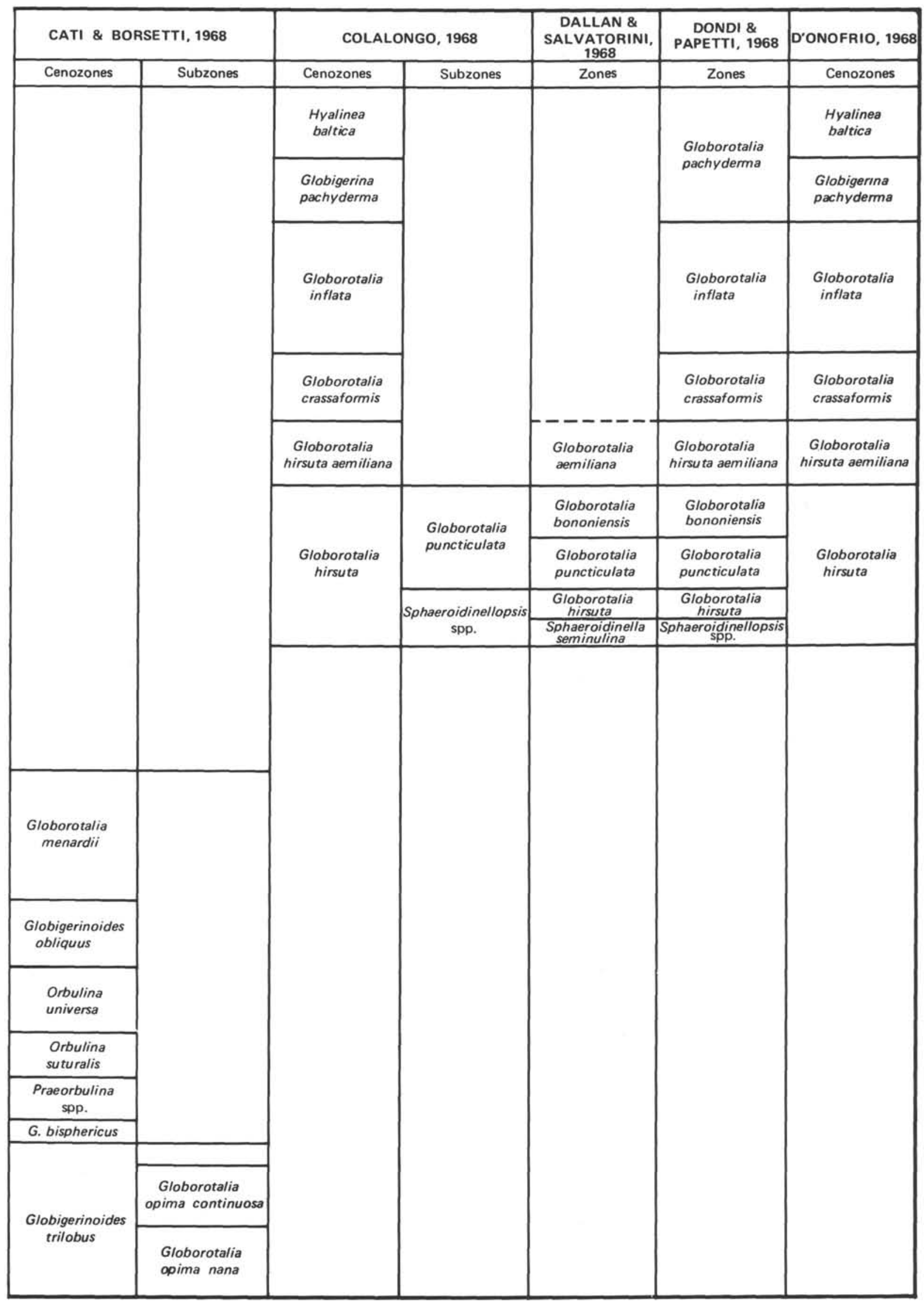

Figure 2. (Continued). 


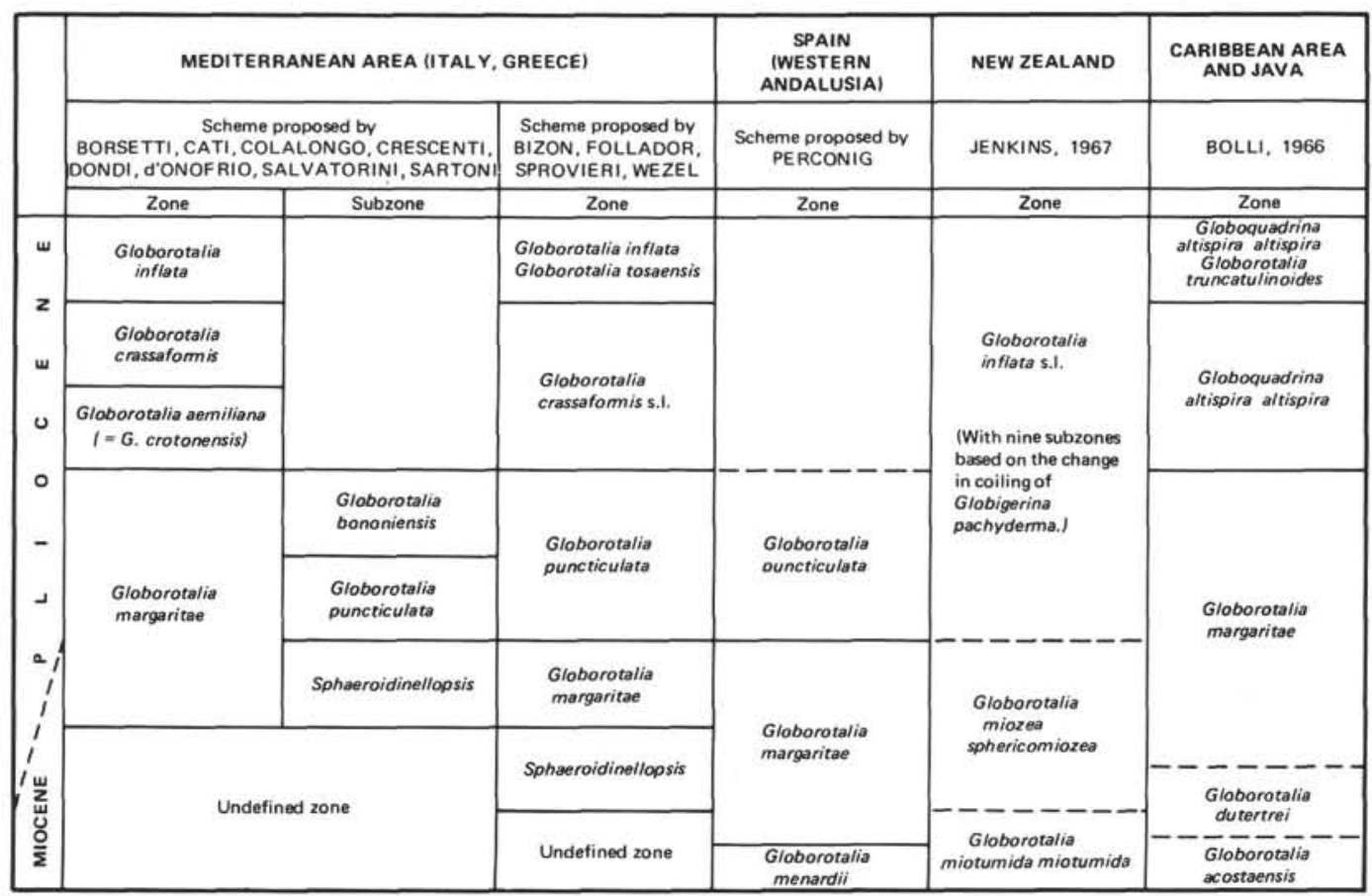

Figure 3. Zonal scheme for the Pliocene of the Mediterranean area based on planktonic foraminifers (after Cati et al., 1968).

mum water depth of the seas is interpreted to have been that of outer shelf toward the slope during Tabianian time, and the minimum water depth at the end of Pliocene was within the limits of the sublittoral or littoral zone.

Planktonic foraminifers of the Tabianian stratotype (Early Pliocene), as described by Iaccarino (1967), include (a) warm-water species such as Sphaeroidinellopsis sphaeroides ( $=S$. seminulina of authors) and Globoquadrina altispira which make their last appearance in northern Italy during the Tabianian, (b) Globorotalia margaritae ( $=G$. hirsuta of authors) which is restricted to the Tabianian, and (c) G. crassaformis gens which appear first in the Tabianian. Assemblages contain common Globigerina spp. and Globigerinoides spp.; Globorotalia inflata first appears in the upper Plaisancian slightly below the earliest Globigerina pachyderma.

The stratigraphic distribution of important late Neogene planktonic species in northern Italy is given in Figure 4. On the planktonic scale the Tabianian is equivalent to the Globorotalia margaritae Zone (Early Pliocene) and the Plaisancian to the $G$. crassaformis and $G$. inflata Zone (Middle and Late Pliocene).

Although Wezel (1968) and Follador (1967) record Globorotalia truncatulinoides as appearing first in the very late Pliocene, current opinion, supported by study of occurrences in the type region of the Calabrian Stage, regards this species as restricted to Calabrian and younger intervals and as first occurring commonly in the Sicilian Stage (Gradstein, 1970). There is possibly some confusion among authors with $G$. tosaensis, a closely related species, which is reported to occur rarely in the late Pliocene of Italy. Although the complete bioseries leading to Sphaeroidinella dehiscens has not been documented in Italy, $S$. dehiscens is reported from the late Pliocene by Follador (1967) and Sphaeroidinellopsis sphaeroides (=S. seminulina of authors) from the early and early middle Pliocene by many authors. One the basis of available evidence, no occurrence for $S$. dehiscens s.s. is older than late Pliocene.

In tropical regions Hays et al. (1969) showed the range of Globorotalia margaritae to fall within the Gilbert Event (greater than 4.5 m.y. to about 3.3 m.y.) and that of Sphaeroidinella dehiscens s.s. to begin at about the top of the Mammouth Event (at 3.0 m.y.).

\section{Calabrian Stage (Early Pleistocene)}

No specific or generally accepted type section exists for the Calabrian, although the region of Calabria is the type locality. At the 19th International Geological Congress in Algiers in 1952, four type sections were proposed; Monte Mario (Roma), Castell'Arquato (Emilia), Santerno (Romagna), and Musone (Marche). None of these has received popular support, except perhaps the Castell'Arquato by Ruggieri (1965). In the region of Calabria, Emiliani et. al. (1961) selected the LeCastella section for detailed isotopic analysis, maintaining that it was more completely exposed than the Santa Maria di Catanzaro section of Gignoux (1913). They demonstrated climatic fluctuations above a proposed Pliocene-Pleistocene boundary determined by the first appearance of Hyalinea baltica. Selli (1967b) stated a preference for the section at 


\begin{tabular}{|c|c|c|c|c|}
\hline EPOCH & LATE MIOCENE & & IOCENE & PLEISTOCENE \\
\hline STAGE & MESSINIAN & $\begin{array}{l}\text { TABIAN- } \\
\text { IAN* }\end{array}$ & $\begin{array}{l}\text { PLAISANCIAN } \\
\text { ASTIAN*** }\end{array}$ & EARLY CALABRIAN* \\
\hline $\begin{array}{l}\text { Globigerina nepenthes } \\
\text { Globigerina eggeri (s.I.) } \\
\text { Sphaeroidinellopsis sp. } \\
\text { Globorotalia crassaformis (s.l.) } \\
\text { Globorotalia margaritae } \\
\text { = G. hirsuta of authors) } \\
\text { Globoquadrina altispira } \\
\text { Globigerinoides conglobatus } \\
\text { Globorotalia inflata } \\
\text { Globigerina pachyderma } \\
\text { Hyalinea baltica }\end{array}$ & $\begin{array}{l}\text { "Locally transgressive } \\
\text { * Locally regressive }\end{array}$ & $\begin{array}{l}\mathrm{i} \\
\mathrm{i} \\
\mathrm{i} \\
\mathrm{i} \\
\mathrm{i} \\
\mathrm{i} \\
\mathrm{i}\end{array}$ & 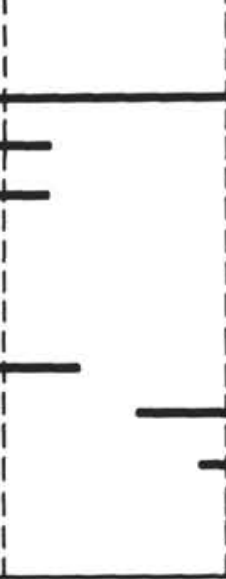 & 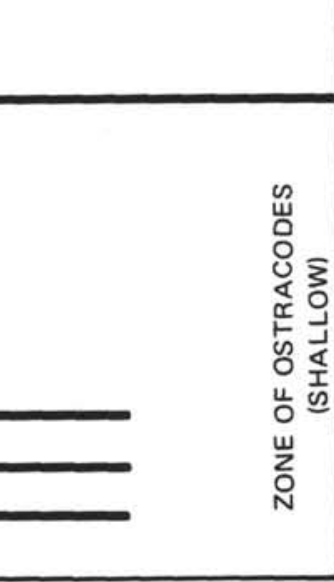 \\
\hline
\end{tabular}

Figure 4. Stratigraphic distribution of some planktonic foraminifers in the sub-Apennine region of northern Italy (after Pezzani, 1963; Barbieri, 1967; Iaccarino, 1967; and Barbieri and Petrucci, 1957).

Santa Maria di Catanzaro which he provisionally dedicated as the stratotype. Although he discussed the incursion of boreal species as fundamental in defining the Calabrian, the planktonic biostratigraphy was not described.

Following recommendations of the 18th International Geological Congress (1950), the base of the Quaternary or Pleistocene is widely accepted as being at the horizon of the first indication of climatic deterioration in the Italian Neogene succession. The Commission recommended further that the lower Pleistocene should include as its basal member in the type area the Calabrian Formation (marine), together with its terrestrial equivalent, the Villafranchian.

The work of Gignoux (1913) in the type area, where he described the Calabrian Stage, emphasized onset of climatic deterioration as recognized by the sudden appearance in the Mediterranean region of "northern guest" species, such as Arctica islandica.

The beginning of glaciation per se can be demonstrated most effectively by physical evidence, such as glacial till, in continental sequences and evidence for lowering of sea level within marine sequences in reasonably tectonically stable regions (Smith, 1965; Beard and Lamb, 1968). The stratigraphic succession in northern Italy seemingly is ideal to demonstrate a relationship between the faunal (climatic) and eustatic events; namely, marine regressive upper Pliocene (Astian) strata grade upward into continental beds (Villafranchian) which precede and are laterally equivalent in part to marine Calabrian strata. Although Villafranchian and Calabrian deposits are not contiguous, it is feasible, because of their stratigraphic position above the Astian sandstones, to equate the Villafranchian with possibly upper Pliocene and also lower Pleistocene marine strata.

Bayliss (1969) studied the stratigraphic distribution of the foraminifers Globorotalia truncatulinoides and Hyalinea baltica, together with the mollusk Arctica islandica, in the area of the Calabrian at Santa Maria di Catanzaro in southern Italy. He maintained that the species first appeared at different horizons. If the first occurrence of $H$. baltica is taken as the horizon to begin the Pleistocene, then the Plio-Pleistocene boundary would be below the lowest bed exposed in the Santa Maria di Catanzaro section. In this case, he argued, the boundary cannot coincide with Gignoux's which was determined with $A$. islandica.

Bayliss's study in part supports the Committee's recommendations for recognizing certain faunal criteria in defining the upper limits of the Pliocene, which become ipso facto the limiting criteria for defining the lower limits of the Calabrian Stage. A number of authors have expressed the opinion that the upper boundary of the Pliocene corresponds with (a) the increase in frequency and change in coiling (i.e., entry of sparse left-coiling forms) of Globigerina pachyderma, (b) the first appearance of Globorotalia truncatulinoides (only in some regions), and (c) the appearance of "northern guests" or boreal species such as Hyalinea baltica and Artica islandica.

Thus, on the basis of foraminiferal evidence, the base of the Calabrian Stage is not completely exposed at Santa Maria di Catazaro because it falls within the 30 meters of covered section below the lower sandstones. This covered interval has Pliocene strata below and Pleistocene strata above.

Smith (1969) was the first to publish the calcareous nannofossil sequence within the Pleistocene sections at LeCastella and Santa Maria di Catanzaro. His was also the earliest biostratigraphic correlation of the Santa Maria Catanzaro and LeCastella (Telegrafo) sections. He gave cogent reasons for believing that the Telegrafo Section at LeCastella is mainly Emilian equivalents (warm) and younger than the Calabrian at Santa Maria (Figure 5).

At Telegrafo, the so-called "Pliocene-Pleistocene boundary" of Emiliani et al. (1961), Emiliani (1971), Bandy and Wilcoxon (1970), and Nakagawa et al. (1971), as was pointed out by McIntyre et al. (1967), Smith (1969), and Bandy and Wilcoxon (1970), marks a distinct change from 


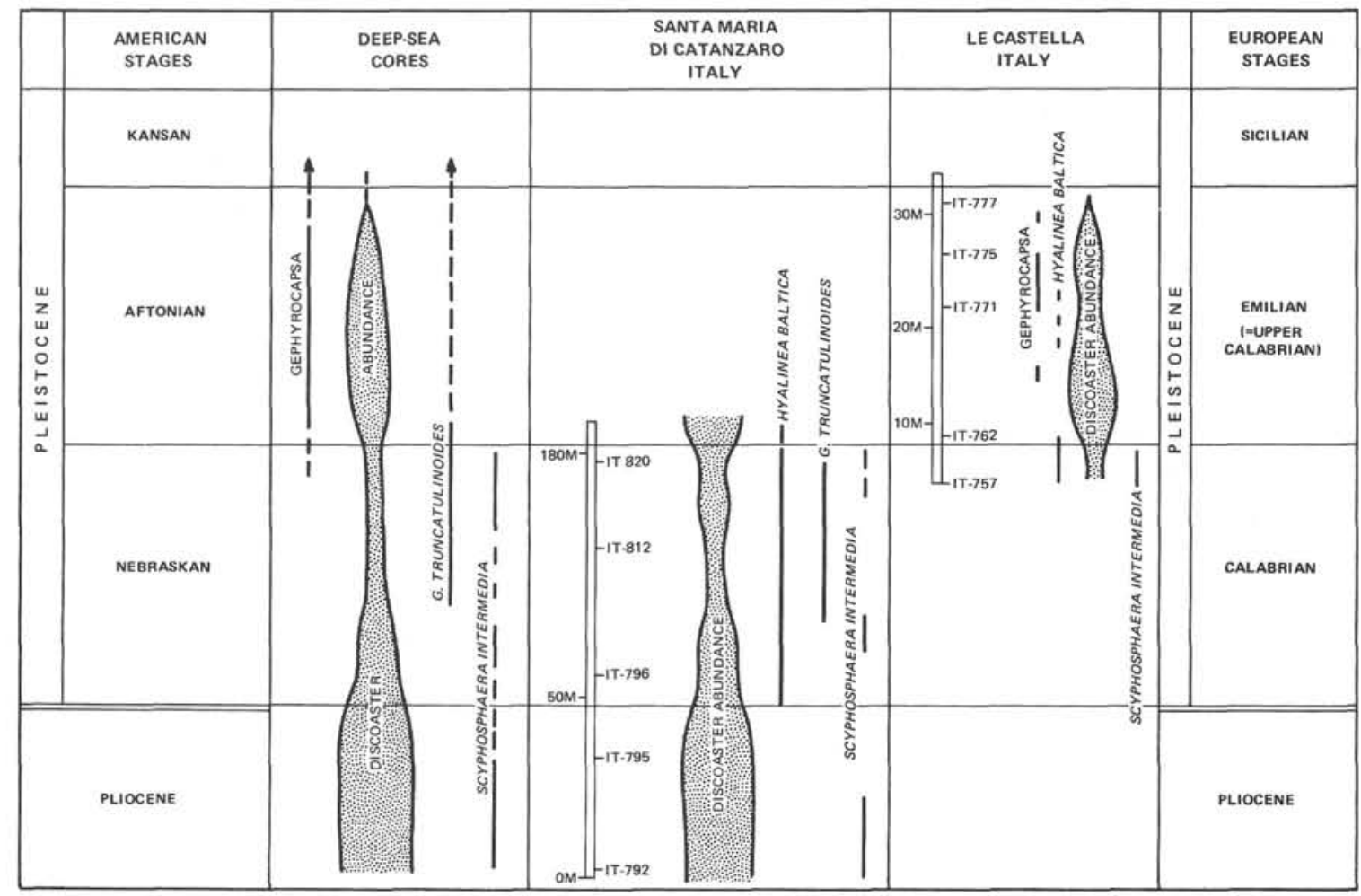

Figure 5. Correlation section for the stratotype Calabrian and Le Castella sections of Italy and a generalized section from oceanic sediments.

cool to warm conditions in oceanic waters. The evident change from cool to warm is not likely to represent the Pliocene-Pleistocene boundary and cannot correlate with the base of the Calabrian.

At Santa Maria di Catanzaro, Discoaster brouweri ranges concurrently with Globorotalia truncatulinoides. In the Gulf of Mexico sections this overlap occurs only in the Nebraskan (cool) and Aftonian (warm). Since the Calabrian at Santa Maria represents cooler water deposition, it must equate with the Nebraskan. At LeCastella, in the Telegrafo section, Discoaster brouweri ranges concurrently with Gephyrocapsa oceanica in a section representing warmer water deposition. In the Gulf of Mexico sections this overlap occurs only in the Aftonian (warm). The Emilian of the Telegrafo section must equate with the American marine Aftonian.

The samples used by Emiliani et al. (1961) were actually collected at LeCastella by Prof. Guilio Carloni, University of Bologna. They were from two separate sections along the coast, at Torre Brasolo and Telegrafo (Figure 6). Although, in the published work, the samples were assumed to represent a continuous sequence, the SE dip of the beds is sufficient to render the sampling incomplete. The upper samples from Torre Brasolo are Middle Pliocene and the lower samples from Telegrafo are Late Calabrian. For Beard (1969), Lamb (1969), and Smith (1969), Prof. Carloni returned to LeCastella and recollected the same sections at Torre Brasolo and Telegrafo used by Emiliani et al. (1961). The study of these samples indicated the relationships documented by Smith (1969) (Figure 5) that the Late Pliocene and earliest Pleistocene had not been sampled.

As shown in Figure 6, we sampled four additional sections between Torre Brasolo and Telegrafo. Detailed study of foraminifers from all six sections and paleomagnetic determinations on 73 samples have been reported by Lamb (1971). He points out that the "PliocenePleistocene boundary" of Emiliani et al. (1961)-the so-called "marker bed" (our sample 761)-was designated as the boundary by Carloni on "field evidence," rather than being determined as such by study of the samples. Carloni evidently mistook the coarser bed for sand and correlated it with the turbiditic units of the basal Calabrian at Santa Maria di Catanzaro. As determined by Lamb (1971), the bed in question is almost entirely foraminiferal tests, with no terrigineous clastics included-the least likely bed for the correlation that Carloni assumed. Yet Carloni's "boundary" seemingly goes unquestioned to this day by those equipped to correct his miscorrelation.

The data presented by Bandy and Wilcoxon (1970) also proves that the "marker bed" cannot be equated to basal Calabrian, marking, as it does, a change from cool (below) to warm (above). The coiling changes in Globigerina pachyderma, noted by Bandy and Wilcoxon (1970) from the upper samples at Telegrafo (LeCastella), correlate with those noted from the type Sicilian at Ficarizzi (Gradstein, 1970; Lamb, 1971) and not with the Calabrian at Santa Maria di Catanzaro or elsewhere. Neither does the so-called boundary in the Telegrafo section correlate with that used by many workers in deep-sea sediments.

That the extinction of Discoaster brouweri occurs within the warm unit above the first cool unit, rather than at the boundary between them, has been demonstrated in many places and is here documented from the Gulf of Mexico. The extinction of Discoaster brouweri, which has been shown to occur at or within the Olduvai (Gilsa), between 1.6 and 1.8 m.y. B.P., cannot even be as old as the "marker 


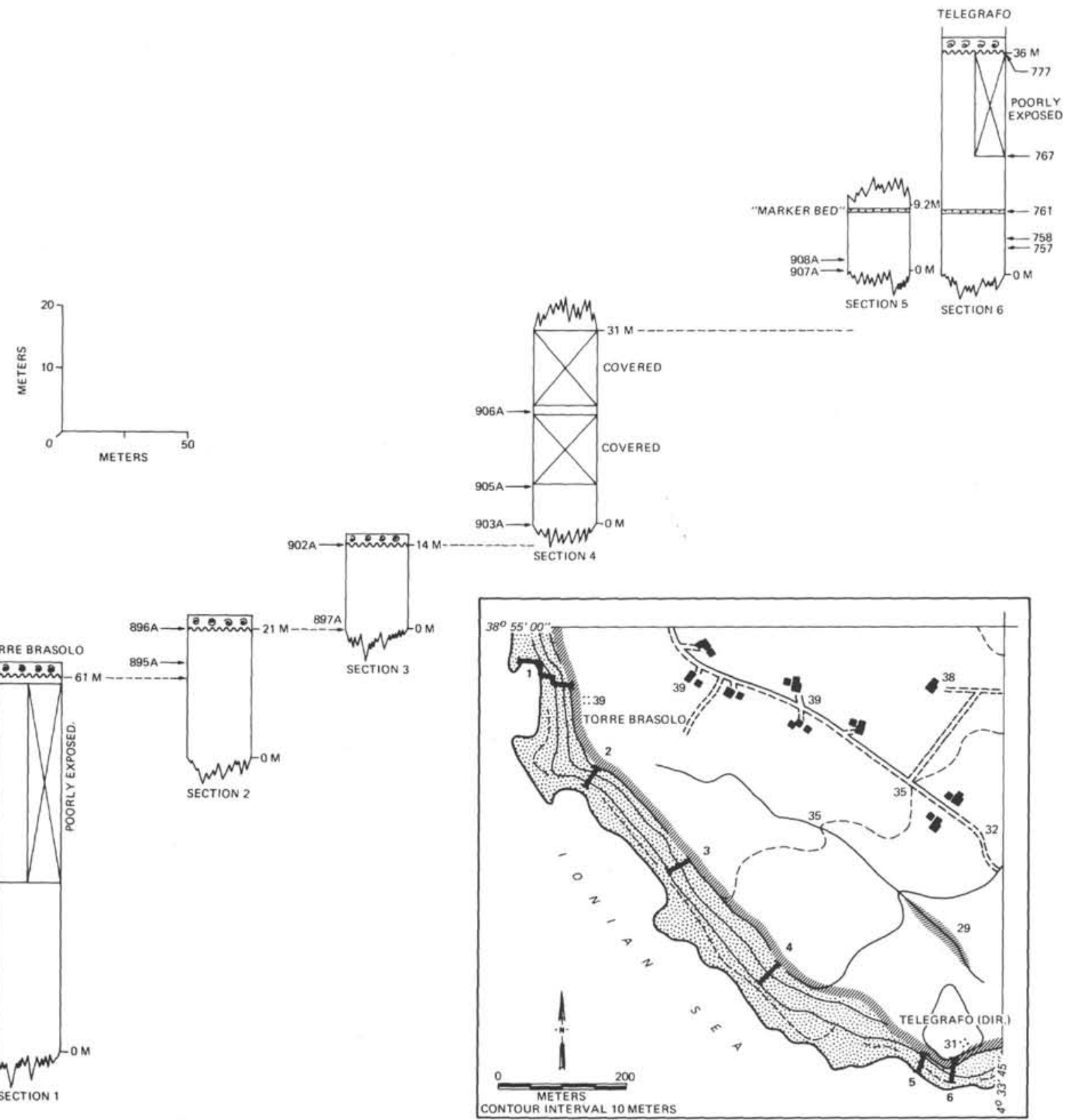

Figure 6. Correlation of stratigraphic sections measured between Torre Brasolo and Telegrafo Point, near Le Castella in southern Italy. (Longitude is in reference to the meridian of Rome, corresponding approximately to $17^{\circ} 01^{\prime}$ E of Greenwich).

bed" in the Telegrafo section (the Calabrian-Emilian boundary=Nebraskan-Aftonian boundary in the Gulf of Mexico). The 1.8 m.y. date, being used for the "PliocenePleistocene" in deep-sea sediments is more nearly an age for the Emilian-Sicilian (=Aftonian-Kansan) boundary.

There is no doubt that the Italian stratotype sections include much reworked older Neogene calcareous nannofossils. This does not, however, negate the fact that the overlapping ranges of Globorotalia truncatulinoides and Discoaster brouweri include only Early Pleistocene sediments there and elsewhere. Their concurrence was not established in the Italian sections but was observed there (Smith, 1969). It is here documented from the Gulf of Mexico and, considering that the evolutionary appearance of Globorotalia truncatulinoides is recorded within the stratotype Calabrian, it cannot be considered other than Pleistocene.

The Pliocene-Pleistocene boundary is older than the base of Olduvai $( \pm 1.8$ m.y.). (Emilian $=$ Aftonian). It also must predate the "marker bed" in the Telegrafo section at LeCastella (Calabrian-Emilian $=$ Nebraskan-Aftonian bound ary). The boundary is defined as the base of the Calabrian and recognized in the type sections by the arrival of "northern guests" (onset of cooling) following the warm Pliocene. All of the absolute ages on evidence for this cooling, tills, ice-rafted glacial debris, etc., fall between 2.5 and $3.0 \mathrm{~m} . \mathrm{y}$. We have, therefore, taken as the approximate age of the Pliocene-Pleistocene boundary $2.8 \mathrm{~m} . \mathrm{y}$. It is entirely possible that the boundary is $3.0 \mathrm{~m} . \mathrm{y}$. B.P., as suggested by Berggren's work on DSDP Leg 12 in the North 
Atlantic (1972), but it is absolutely impossible for it to be as young as $1.8 \mathrm{~m} . y$. (probably no younger than 2.5 , or, for those preferring the advent of man as the beginning of the Pleistocene, no younger than 2.6 m.y. B.P.).

The preceding discussion gives evidence for a broad subdivision of the Italian Late Neogene planktonic succession along the following lines:

1) The Tortonian (late Miocene) includes a short interval of the Globorotalia menardii Zone followed upward by an interval characterized by the first occurrence of Globorotalia acostaensis. For the practical purpose of faunal correlation it is desirable to begin the Tortonian Stage with the first appearance of $G$. acostaensis.

2) For reasons given, the Messinian (Late Miocene) does not lend itself to extra-Mediterranean comparison on the basis of planktonic foraminifers. The lower boundary is arbitrary, as is the upper limit of the Tortonian. Globigerinoides conglobatus, Sphaeroidinellopsis sphaeroides, and Globorotalia acostaensis are among those species that occur in the Late Messinian. Much of the Messinian is characterized by evaporites.

3) The lower limit of the Tabianian (Early Pliocene) corresponds closely with the earliest occurrence of Globorotalia margaritae followed upward by the appearance of $G$. puncticulata and $G$. bononiensis.

4) The Plaisancian (Middle-late Pliocene) begins with the earliest occurrence of Globorotalia aemiliana and $G$. crassacrotonensis followed upward by $G$. crassaformis sensu stricto, G. inflata, Globigerina pachyderma, Sphaeroidinella dehiscens.

5) The upper limit of the Pliocene or beginning of the Calabrian Stage corresponds with the earliest occurrence of northern guest species such as Arctica islandica, Hyalinea baltica, left-coiling forms of Globigerina pachyderma, and decrease in the percentage of warm-water planktonic species. The first occurrence of Globorotalia truncatulinoides sensu stricto is above the base of the Calabrian.

\section{SUMMARY OF PLANKTONIC ZONATIONS}

\section{Planktonic Foraminifers}

Descriptions of the Late Middle Miocene to Holocene planktonic zones applied in this study are given (Figure 7). A full description and documentation of the zones, as well as stereoscan illustrations of the planktonic foraminiferal species was published by Lamb and Beard (1972).

\section{LATE MIDDLE MIOCENE}

Globorotalia menardii Zone

Author: Stainforth, 1948, p. 1303.

Definition: Interval with zonal marker, from last occurrence of Globorotalia siakensis to first occurrence of Globorotalia acostaensis.

\section{LATE MIOCENE}

Globorotalia acostaensis Zone

Author: Lamb and Beard, 1972.

Definition: Interval with zonal marker, from its first occurrence to first occurrence of Globorotalia margaritae.
Sphaeroidinellopsis seminulina Subzone

Author: Lamb and Beard, 1972.

Definition: Interval with zonal marker, from the first occurrence of Globorotalia acostaensis to last occurrence of zonal marker.

Remarks: Globorotalia lenguaensis and Globoquadrina dehiscens have their last occurrence in the subzone, and Globigerinoides obliquus extremus has its first occurrence in the upper part of the subzone.

Sphaeroidinellopsis sphaeroides Subzone

Author: Lamb and Beard, 1972.

Definition: Interval with zonal marker, from its first occurrence to first occurrence of Globorotalia margaritae.

Remarks: Globoquadrina humerosa and Globigerinoides conglobatus have their first occurrence in the upper part of this subzone.

\section{PLIOCENE}

Globorotalia margaritae Zone

Author: Bolli and Bermúdez, 1965, p. 132.

Definition: Range of zonal marker.

Globorotalia multicamerata Subzone

Author: Lamb and Beard, 1972.

Definition: Interval from first occurrence of Globorotalia margaritae to first occurrence of Pulleniatina primalis.

Remarks: G. aemiliana, and G. crassacrotonensis have their first occurrence in this subzone.

Pulleniatina primalis Subzone

Author: Lamb and Beard, 1972.

Definition: Interval with zonal marker, from its first occurrence to the last occurrence of Globorotalia margaritae.

Remarks: Globigerina nepenthes and Globorotalia crassacrotonensis have their last occurrence in this subzone.

Pulleniatina obliquiloculata Zone

Author: Lamb and Beard, 1972.

Definition: Interval from last occurrence of Globorotalia margaritae to the extinction horizon of Globoquadrina altispira.

Remarks: Glorobotalia praehirsuta, $G$. inflata, $G$. tosaensis, G. pertenuis, G. miocenica, s.s., Pulleniatina obliquiloculata (in tropical regions), and Sphaeroidinella dehiscens have their first occurrence in this zone.

\section{PLEISTOCENE}

\section{Globorotalia truncatulinoides Zone}

Author: Lamb and Beard, 1972.

Definition: Interval from the extinction horizon of Globoquadrina altispira to the first occurrence of large forms of the species Globorotalia tumida in the Gulf of Mexico region.

Globorotalia tosaensis Subzone

Author: Lamb and Beard, 1972.

Definition: Interval with zonal marker, from the horizon of extinction of Globoquadrina altispira to last occurrence of zonal marker.

Remarks: In upward fashion, Globigerinoides obliquus extremus, Globorotalia multicamerata, G. miocenica, and $G$. pertenuis have their last occurrence in this 


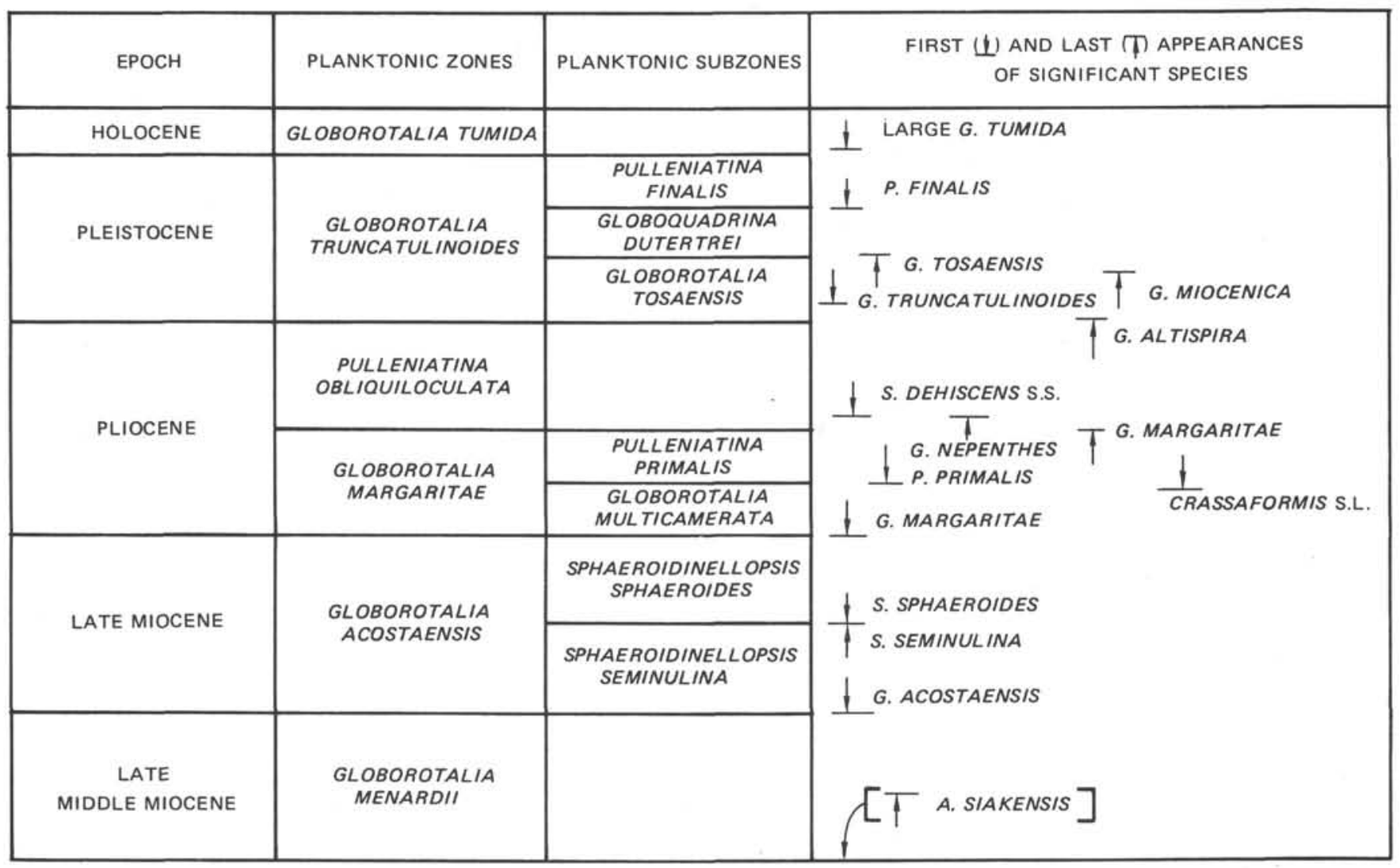

Figure 7. Miocene to Holocene planktonic foraminiferal zonation.

subzone. Globorotalia menardii reappears in the upper part of the subzone in the Gulf of Mexico region during the Aftonian warm interglacial period. The horizon of extinction of $G$. miocenica within this subzone is considered by some oil company paleontologists to mark the upper limit of the Nebraskan glacial stage. This species is reliable for subdividing the $G$. tosaensis Subzone in the Gulf of Mexico and the Caribbean.

Globoquadrina dutertrei Subzone

Author: Lamb and Beard, 1972.

Definition: Interval with zonal marker above last occurrence of Globorotalia tosaensis to first occurrence of Pulleniatina finalis.

Remarks: The first abundant Globorotalia truncatulinoides occur at the base of this subzone with large, turbinate forms of Globoquadrina dutertrei.

Pulleniatina finalis Subzone

Author: Lamb and Beard, 1972.
Definition: Interval from the first occurrence of Pulleniatina finalis to first occurrence of large forms of Globorotalia tumida sensu stricto.

Remarks: The development of Pulleniatina finalis from $P$. obliquiloculata characterizes the base of the zone. Globorotalia flexuosa, G. inflata, and Globigerina hexagona have their last occurrence in this subzone in the Gulf of Mexico.

\section{HOLOCENE}

Globorotalia tumida Zone

Author: Lamb and Beard, 1972. [=Holocene (postglacial)].

Definition: Interval with very large forms of the species Globorotalia tumida.

Remarks: Base of zone in Gulf of Mexico is characterized by a faunal boundary between cold-water species such as Globorotalia inflata below and warm-water species such 
as $G$. tumida (large forms) and common $G$. menardii above. The boundary seems to correspond to the end of the last glacial period and the beginning of the Holocene Epoch. (Beard, in press).

\section{Calcareous Nannofossils}

Calcareous nannofossil-based zones were not used in the shipboard reporting. Dating with calcareous nannofossils for Leg 10 has been in terms of planktonic foraminiferal zonal equivalency, primarily because of the confusion of ill-defined calcareous nannofossil zonal nomenclature already in existence at the time of the cruise. The situation has improved somewhat, but different authors are still treating formally named zones differently, with or without obvious emendation. The planktonic foraminiferal-based zonation scheme is still better defined and better known because the precise ranges are well documented for most parts of the Cenozoic. Defined biostratigraphic units, whether range, concurrent-range, or partial-range zones, are, in any case, more for purposes of communication than for application by the expert worker. There are too many possibilities for the absence of a species within its life zone for precision based on one or two forms.

Despite these well-understood shortcomings, many readers will be interested in the application of the better known calcareous nannofossil zones to material from which the species occurrences are documented in terms of datums based on appearances and extinctions of planktonic foraminifers. For this purpose, the calcareous nannofossil zonation scheme of Martini (1971) was chosen. It is, of course, a compilation of the works of several authors, but is the best known scheme for the complete Cenozoic.

Martini (1971) draws mainly from Hay et al. (1967), Bramlette and Wilcoxon (1967), Gartner (1969), Martini and Worsley (1970), and Martini (1970). In the summary of data from Leg 10 coreholes on the distribution of planktonic foraminifers and calcareous nannofossils (Figure 8), the calcareous nannofossil zones are applied as defined by Martini (1971). Several problems arose in the rigorous application to well-documented calcareous nannofossil distribution. In one case, for example, Zone NN-17, the interval of deposition represented seemingly is almost of too short a duration to be useful, at least for work with discontinuous coring. The maximum separation between the last occurrence of Discoaster surculus and the last occurrence of $D$. pentaradiatus found was $42 \mathrm{~cm}$ (Core 1 , Hole 97). Additionally, the last occurrences of both species consistently fall within the Pleistocene, rather than Pliocene as indicated by Martini (1971). In another case, the occurrences in the sections from the Gulf of Mexico would not allow separation of Zones NN-10, NN-11, and NN-12, because indicated ranges for the definitive species do disagree markedly with those previously published.

Following is a brief summary of the late Middle Miocene to Holocene calcareous nannofossil zones as defined by Martini (1971). In each case, the original authorship is indicated, the definition is given, and brief notes on associated species are included. Difficulties encountered with the zonal application, as defined, are mentioned in the remarks.

\section{LATE MIDDLE MIOCENE TO LATE MIOCENE}

\section{NN-9 - Discoaster hamatus Zone}

Author: Bramlette and Wilcoxon, 1967.

Definition: Interval from the first occurrence to the last occurrence of Discoaster hamatus.

Associated Species: Discoaster variabilis, D. challengeri, $D$. calcaris, $D$. exilis, and $D$. bollii.

Remarks: As indicated by Martini (1971), the zone seems to span the Middle to Late Miocene boundary. The end of Middle Miocene may be approximated by the last occurrence of Triquetrorhabdulus rugosus Bramlette and Wilcoxon.

\section{LATE MIOCENE}

\section{NN-10 - Discoaster calcaris Zone}

Author: Martini, 1969.

Definition: Interval from the last occurrence of Discoaster hamatus to the first occurrence of $D$. quinqueramus.

Associated Species: Martini (1971) states that Catinaster calyculus and Discoaster bollii have their last occurrence and Sphenolithus abies its first occurrence in the lower part of the zone.

Remarks: Since NN-9 is defined as a range-zone for Discoaster hamatus Martini and Bramlette and our data indicate an overlap of that species with $D$. quinqueramus Gartner, we were unable to recognize zone NN-10. This does not, however, preclude its existence as a valid zone because we were not separating $D$. neohamatus Bukry and Bramlette at the time of this work. Martini's remarks indicate that the zone would be restricted to the Late Miocene, but we record Discoaster quinqueramus Gartner overlapping with $D$. bolli Martini and Bramlette, so that application of the zone is probably not without difficulties.

\section{LATE MIOCENE TO EARLY PLIOCENE}

NN-11 - Discoaster quinqueramus Zone

Author: Gartner, 1969.

Definition: Interval from the first to the last occurrence of Discoaster quinqueramus.

Associated Species: Discoaster variabilis, D. challengeri, D. brouweri, D. pentaradiatus, and Sphenolithus abies.

Remarks: Since we record a much longer range for the nominate species than does Martini (1971), it is difficult to say more than that the zone probably does straddle the Miocene-Pliocene boundary.

\section{PLIOCENE}

\section{NN-12 - Ceratolithus tricornulatus Zone}

Author: Gartner, 1969.

Definition: Interval from the last occurrence of Discoaster quinqueramus to the first occurrence of Ceratolithus rugosus.

Associated Species: Discoaster surculus, D. pentaradiatus, D. variabilis, D. brouweri, and Reticulofenestra pseudoumbilica.

Remarks: The nominate species is not common in our material, yet we record an overlap of Discoaster quinqueramus Gartner and Ceratolithus rugosus Bukry and Bramlette. We cannot, therefore, precisely place the zone, if indeed it exists. 
NN-13 - Ceratolithus rugosus Zone

Author: Gartner, 1969.

Definition: Interval from the first occurrence of Ceratolithus rugosus to the first occurrence of Discoaster asymmetricus.

Associated Species: Discoaster variabilis, $D$. surculus, $D$. pentaradiatus, $D$. brouweri, and Reticulofenestra pseudoumbilica.

Remarks: Neither of the definitive species is common in the Gulf of Mexico (Leg 10) sections. This is, however, the oldest of the Late Neogene zones that can be placed, as defined, where it was originally conceived by the author (late Early Pliocene).

NN-14 - Discoaster asymmetricus Zone

Author: Gartner, 1969.

Definition: Interval from the first occurrence of Discoaster asymmetricus to the last occurrence of Ceratolithus tricornulatus.

Associated Species: Reticulofenestra pseudoumbilica, Sphenolithus abies, Discoaster variabilis, D. surculus, D. pentaradiatus, and $D$. brouweri.

Remarks: Neither of the definitive species is common in the Leg 10 cores, but, applied to the occurrences, the zone seemingly falls entirely within the Middle Pliocene and approximates the Pulleniatina primalis Subzone.

NN-15 - Reticulofenestra pseudoumbilica Zone

Author: Gartner, 1969.

Definition: Interval from the last occurrence of Ceratolithus tricormulatus to the last occurrence of Reticulofenestra pseudoumbilica.

Associated Species: Discoaster variabilis, $D$. surculus, $D$. pentaradiatus, D. brouweri, and Cyclococcolithus macintyrei.

Remarks: As conceived by its author, the top of this zone would mark the base of the Nebraskan. This is the last common occurrence of the species rather than its extinction, however, and, if it is to be used in the sense originally intended, must be emended. The most abundant occurrences of the nominate form in the Gulf of Mexico sections are below the zone, as defined. The end of the Pliocene is more nearly marked by the extinction of Discoaster variabilis Martini and Bramlette; Sphenolithus abies Deflandre becomes extinct at about the middle of the zone.

\section{PLEISTOCENE}

NN-16 - Discoaster surculus Zone

Authors: Hay and Schmidt, in Hay et al., 1967; emended Gartner, 1969.

Definition: Interval from the last occurrence of Reticulofenestra pseudoumbilica to the last occurrence of Discoaster surculus.

Associated Species: Discoaster pentaradiatus, D. brouweri, D. asymmetricus, Ceratolithus rugosus, Cyclococcolithus macintyrei, and Pseudoemiliania lacunosa.

Remarks: Since the nominate species occurs with Globorotalia truncatulinoides (d'Orbigny) in sediments deposited after the onset of cooling both in the Gulf of Mexico and in the Italian stratotypical Calabrian, it is probably entirely Pleistocene in age.
NN-17 - Discoaster pentaradiatus Zone

Authors: Martini and Worsley, 1970.

Definition: Interval from the last occurrence of Discoaster surculus to the last occurrence of $D$. pentaradiatus.

Associated Species: Discoaster brouweri, Cyclococcolithus macintyrei, Helicopontosphaera sellii, and Pseudoemiliania lacunosa.

Remarks: In the Gulf of Mexico cores (Leg 10) this zone could not demonstrably be more than $42 \mathrm{~cm}$ in vertical thickness and probably does not represent much time. Gartner (1969) also reported a thickness for the interval of only $40 \mathrm{~cm}$ from the Atlantic and did not choose to propose it as a zone.

NN-18 - Discoaster brouweri Zone

Authors: Hay and Schmidt, in Hay et al., 1967; emend. Martini and Worsley, 1970.

Definition: Interval from the last occurrence of Discoaster pentaradiatus to the last occurrence of $D$. brouweri.

Associated Species: Cyclococcolithus macintyrei, Coccolithus pelagicus, s.1. (large, with bar), Helicopontosphaera selli, Pseudoemiliania lacunosa, Lithostromation $\mathrm{cf}$. perdurum, and Gephyrocapsa oceanica.

Remarks: The cooccurrence of Globorotalia truncatulinoides (d'Orbigny), Discoaster brouweri Tan Sin Hok, and Gephyrocapsa oceanica Kamptner has been noted only in the warmer interval overlying the first cooler interval post-dating the warm Pliocene. This overlap (D. brouweri and $G$. oceanica) is found within the range of $G$. truncatulinoides both in the stratotype sections of Italy (Emilian) and the Gulf of Mexico (Aftonian). There is little doubt of the correlation of the units and no doubt concerning their Pleistocene age.

NN-19 - Pseudoemiliania lacunosa Zone

Author: Gartner, 1969.

Definition: Interval from the last occurrence of Discoaster brouweri to the last occurrence of Pseudoemiliania lacunosa.

Associated Species: Gephyrocapsa oceanica, Ceratolithus cristatus, Coccolithus pataecus, Oolithotus antillarum, and Discoaster? perplexus.

Remarks: In the Gulf of Mexico the nominate form is usually the dominant species of the assemblage, except in the uppermost part of the zone, where Gephyrocapsa becomes relatively more abundant. The lower third of the zone may be recognized in the Gulf of Mexico by the presence of Cyclococcolithus macintyrei Bukry and Bramlette. The middle third of the zone may be recognized as the interval from the last occurrence of $C$. macintyrei Bukry and Bramlette to the last occurrence of Scyphosphaera pulcherrima Deflandre.

NN-20 - Gephyrocapsa oceanica Zone

Authors: Boudreaux and Hay, in Hay et al., 1967; emend. Gartner, 1969.

Definition: Interval from the last occurrence of Pseudoemiliania lacunosa to the first occurrence of Emiliania huxleyi.

Associated Species: Coccolithus pelagicus, s. s., Ceratolithus cristatus, Helicopontosphaera kamptneri, H. wallachi, and Cyclococcolithus leptoporus.

Remarks: Although neither the base nor top of the zone is defined as the nominate species appearance or extinction, 
it is usually the dominant form in assemblages from the Gulf of Mexico above the extinction of Pseudoemiliania lacunosa (Kamptner). The lower part of the zone may be recognized by the presence of Scyphosphaera recurvata Deflandre.

\section{LATE PLEISTOCENE-HOLOCENE}

NN-21 - Emiliania huxleyi Zone

Authors: Boudreaux and Hay, in Hay et. al., 1967.

Definition: Interval above the first occurrence of Emiliania huxleyi.

Associated Species: Gephyrocapsa oceanica, G. aperta, G. kamptneri, Coccolithus pelagicus, Cyclococcolithus leptoporus, Ceratolithus cristatus, Helicopontosphaera kamptneri, and $H$. wallachi.

Remarks: Considerable difficulty is encountered trying to recognize the nominate species with the light microscope, although it is very distinctive with EM. The species appears in the Late Wisconsinan, but seemingly does not dominate the assemblage until Holocene. There are any number of better ways of recognizing the PleistoceneHolocene boundary.

\section{APPLICATION TO DSDP LEG 10 CORES}

Figure 8 summarizes interpreted ranges, both planktonic foraminifers and calcareous nannofossils, from all of the Late Neogene and Quaternary sections penetrated on DSDP Leg 10. It is considered interpretative because of the discontinuous coring at each site, but, as a composite section of all cores, it leaves very little of the stratigraphic interval unsampled. Both the planktonic foraminiferalbased zonation (Lamb and Beard, 1972) and the calcareous nannofossil zonation (Martini, 1971) are applied, as defined, to the ranges determined for the Gulf of Mexico (Figure 8).

Distribution of the planktonic foraminifers and calcareous nannofossils in cores recovered from each of the DSDP Leg 10 holes $(85,86,88,89,90,91,94$, and 97$)$ are documented on Figures 9 through 16. The remarks concerning each hole are brief, as the figures are considered primary.

\section{Hole 85}

Five Quaternary cores were recovered-the oldest being interpreted as Pleistocene (Illinoian) (Globorotalia truncatulinoides Zone, Globoquadrina dutertrei Subzone). In the calcareous nannofossil-based zonal scheme of Martini (1970), the recovered samples are considered to be representative of his NN-19 to NN-20 (Pseudoemiliania lacunosa to Gephyrocapsa oceanica zones).

The distribution of both planktonic foraminifers and calcareous nannofossils is shown in Figure 9. The Globoquadrina dutertrei-Pulleniatina finalis subzonal boundary is interpreted as occurring within Core 4 , because the earliest occurrence of Pulleniatina finalis is between 42 and $110 \mathrm{~cm}$ in the core. Although Pseudoemiliania lacunosa was not noted, zonal equivalency is inferred because the apparent extinctions of Scyphosphaera recurvata and "Discoaster" perplexus are within Cores 3 and 4 respectively. Pseudoemiliania lacunosa ranges concurrently with Pulleniatina finalis elsewhere and must be absent for reasons other than extinction. It should be noted that Gephyrocapsa oceanica and other delicate forms other than $P$. lacunosa also are absent from Core 3 and rare in Core 4.

Considerable reworking of Cretaceous and Pliocene fossils was noted. The core catcher sample from Core 4 contained definite Pliocene assemblages of both the foraminifers and calcareous nannofossils. Since, however, definite Pleistocene sediments were recovered lower in the section (Core 5), the Pliocene material must have been displaced, probably by slumping from the nearby Campeche Bank.

\section{Hole 86}

Four Late Neogene cores were recovered-the oldest being interpreted as Early Pliocene (Globorotalia margaritae Zone, ?Globorotalia multicamerata Subzone). In the calcareous nannofossil-based zonal scheme of Martini (1971), the recovered samples are considered to be representative of his NN-13 to NN-21 (Ceratolithus rugosus to Emiliania huxleyi Zones).

The distribution of both planktonic foraminifers and calcareous nannofossils is shown in Figure 10. The concurrence of Discoaster brouweri, Gephyrocapsa oceanica, and Globorotalia truncatulinoides is recorded in Core 2. The presence of $G$. truncatulinoides demonstrates that it is Pleistocene and, from the concurrence of $G$. oceanica and $D$. brouweri, it is interpreted to be representative of marine deposition during the Aftonian Interstadial. Globorotalia margaritae occurs in Cores 3 and 4 , and Pulleniatina primalis only in Core 3 , indicating that Core 4 is in the Globorotalia multicamerata Zone. This conclusion as to stratigraphic position is supported by the occurrence in Core 4 of Discoaster subsurculus with Ceratolithus rugosus and below the appearance in Core 3 of Discoaster asymmetricus.

Nannofossil occurrences shown indicate some reworking of Pliocene sediments into the Pleistocene section. This is probably especially true during the cooler low-stands (stadials) and less so during interstadials. It should be kept in mind, however, that the site of drilling is presently on the continental slope and particularly subject to basinward movement of recycled materials. The site may have been in a slope position through much or most of the Quaternary, if not longer.

\section{Hole 88}

Five Late Neogene cores were recovered-the oldest being interpreted as Early to Middle Pliocene (Globorotalia margaritae Zone). In the calcareous nannofossil-based zonal scheme of Martini (1971), the recovered samples are considered to represent his NN-13 to NN-20 (Ceratolithus rugosus to Gephyrocapsa oceanica zones).

The distributions of both planktonic foraminifers and calcareous nannofossils is shown in Figure 11. The concurrence of Discoaster brouweri and Gephyrocapsa oceanica and Globorotalia truncatulinoides is recorded in Core 2. This core is interpreted as primarily Aftonian. The presence of $G$. truncatulinoides with them again illustrates that Discoasters range into the Pleistocene and that their extinction (and the associated so-called Olduvai paleomagnetic event) cannot define the Pliocene-Pleistocene boundary. 
Globorotalia margaritae occurs only in Core 5 and Pulleniatina primalis was not noted from the cored intervals. Since, however, Ceratolithus rugosus occurs in Core 5 and Discoaster asymmetricus appears in Core 4 (NN-13 of Martini, 1971), we may be able to correlate that interval approximately with Core 4 of Hole 86 (Globorotalia multicamerata Subzone).

Most of the detected reworking of older sediments is in section dated as Pleistocene (Wisconsinan). Seemingly, Yarmouthian and Nebraskan age sediments were not cored.

\section{Hole 89}

Six Late Neogene cores were recovered-the oldest being interpreted as early Late Miocene (Globorotalia acostaensis Zone, Sphaeroidinellopsis seminulina Subzone). In the calcareous nannofossil-based zonal scheme of Martini (1971), the recovered samples are considered to be representative of his NN-9 to NN-21 (Discoaster hamatus to Emiliania huxleyi zones).

The distributions of both planktonic foraminifers and calcareous nannofossils is shown in Figure 12. The boundary between the NN-19 and NN-20 (Pseudoemiliania lacunosa and Gephyrocapsa oceanica) zones, would fall somewhere between Cores 1 and 2. The Aftonian (=Emilian) section, with the overlap of Discoaster brouweri and $G$. oceanica, was not cored. However, the concurrence of Globorotalia truncatulinoides and Discoaster brouweri (Nebraskan-Calabrian) in the Early Pleistocene is recorded in Core 3. In Core 6, the concurrence of Globorotalia acostaensis and Discoaster bollii indicates an early Late Miocene age. Some reworking of calcareous nannofossils is evident, but this is primarily in the younger Pleistocene (Core 1).

\section{Hole 90}

Six Late Neogene cores were recovered-the oldest being interpreted as early Late Miocene (Globorotalia acostaensis Zone, Sphaeroidinellopsis seminulina Subzone). In the calcareous nannofossil-based zonal scheme of Martini (1971), the recovered samples are considered to be representative of his NN-9 to NN-20 (Discoaster hamatus to Gephyrocapsa oceanica zones).

The distributions of both planktonic foraminifers and calcareous nannofossils is shown in Figure 13. The section is incompletely cored, the Aftonian, Kansan, Yarmouthian, and Sangamon not being recovered. The concurrence of Discoaster brouweri and Gephyrocapsa oceanica (AftonianEmilian) is not represented, but the overlap of $D$. brouweri with Globorotalia truncatulinoides (Early Pleistocene; Nebraskan-Calabrian) is recorded from Core 3. Core 4 contains Globorotalia margaritae and lacks Pulleniatina primalis, again suggesting Early Pliocene. Some reworking is evident in the Late Pleistocene (Wisconsinan).

\section{Hole 91}

Ten Late Neogene cores were recovered-the oldest being interpreted as early Late Miocene (Globorotalia acostaensis Zone, Sphaeroidinellopsis seminulina Subzone). In the calcareous nannofossil-based zonal scheme of Martini (1971), the recovered samples are considered to be repre- sentative of his NN-9 to NN-20 (Discoaster hamatus to Gephyrocapsa oceanica zones).

The distributions of both planktonic foraminifers and calcareous nannofossils is shown in Figure 14. The section is incompletely cored, Sangamonian, Yarmouthian, and Aftonian age sediments not being recovered. There is considerable reworking of calcareous nannofossils into Kansan and younger sediments. Core 8 is earliest Pleistocene (Early Nebraskan-Early Calabrian), being preGloborotalia truncatulinoides and post-Globoquadrina altispira. Since the rest of Nebraskan and the entire Aftonian were not cored, the Pleistocene overlap of $G$. truncatulinoides and Discoaster brouweri (in situ) is not observed in this hole, according to the ages assigned on the basis of planktonic foraminifers.

\section{Hole 94}

Eight Late Neogene cores were recovered-the oldest being interpreted as late Late Miocene (Globorotalia acostaensis Zone, Sphaeroidinellopsis sphaeroides Subzone). In the calcareous nannofossil-based zonal scheme of Martini (1971), the recovered samples are considered to be representative of his NN-11 to NN-21 (Discoaster quinqueramus to Emiliania huxleyi zones).

The distributions of both planktonic foraminifers and calcareous nannofossils is shown in Figure 15. Coverage (stratigraphic) is incomplete, being best for illustrating the subdivisions of the Pliocene (Cores 2 through 6). Core 1 is Late Wisconsinan to Holocene and Cores 7 and 8 are Late Miocene. Cores 2 through 6 provide good stratigraphic control for marine, essentially pelagic, sedimentation during the Pliocene.

\section{Hole 97}

Three cores were recovered from the Late Neogene-the oldest being early Late Miocene (Globorotalia acostaensis Zone, Sphaeroidinellopsis seminulina Subzone). In the calcareous nannofossil-based zonal scheme of Martini (1971), the recovered samples are considered to be representative of his NN-9 to NN-21 (Discoaster hamatus to Emiliania huxleyi zones).

The distributions of both planktonic foraminifers and calcareous nannofossils is shown in Figure 16. Stratigraphic coverage of the cored intervals is very incomplete. An unconformity of considerable extent (Late Kansan to Middle Wisconsinan) is evidenced within Core 1, and Cores 2 and 3 are representative only of Late Miocene deposition. The overlap of Globorotalia truncatulinoides and Discoaster brouweri (Early Pleistocene) can be seen in the lower part of Core 1.

Core 1, of Hole 97, seemingly provides evidence that Martini's NN-16 and NN-17 are probably not very significant in terms of elapsed time. Martini's NN-16 (the Discoaster surculus Zone of Hay and Schmidt, 1967, emended by Gartner, 1969) is defined as the "interval from the last occurrence of Reticulofenestra pseudoumbilica (Gartner) to the last occurrence of Discoaster surculus Martini and Bramlette." Both these "last occurrences" are in the core catcher sample of Core 1 in Hole 97 (a scant 40 $\mathrm{cm}$ below the next higher sample). 


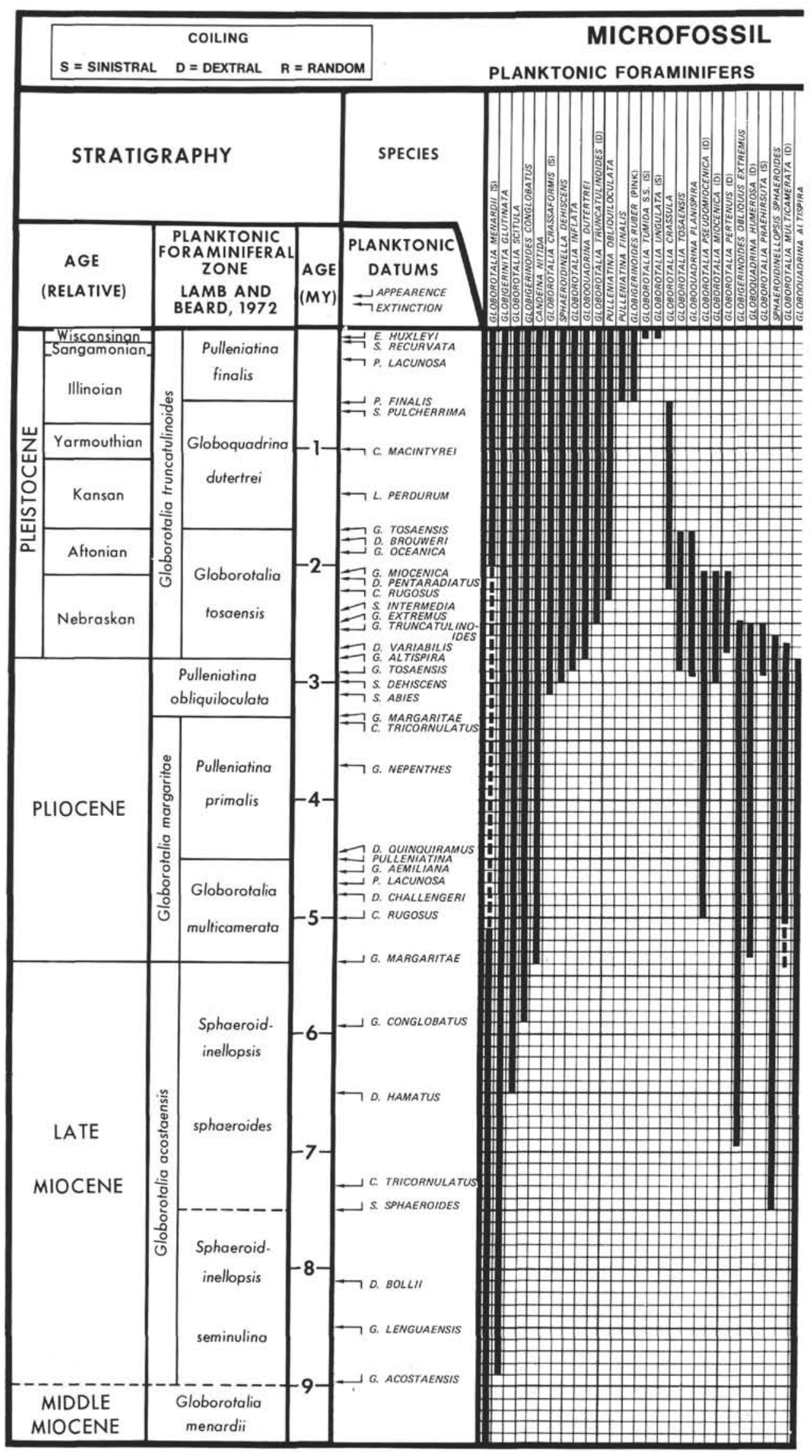

Figure 8. Microfossil distribution chart, DSDP Leg 10, Summary of ranges. 


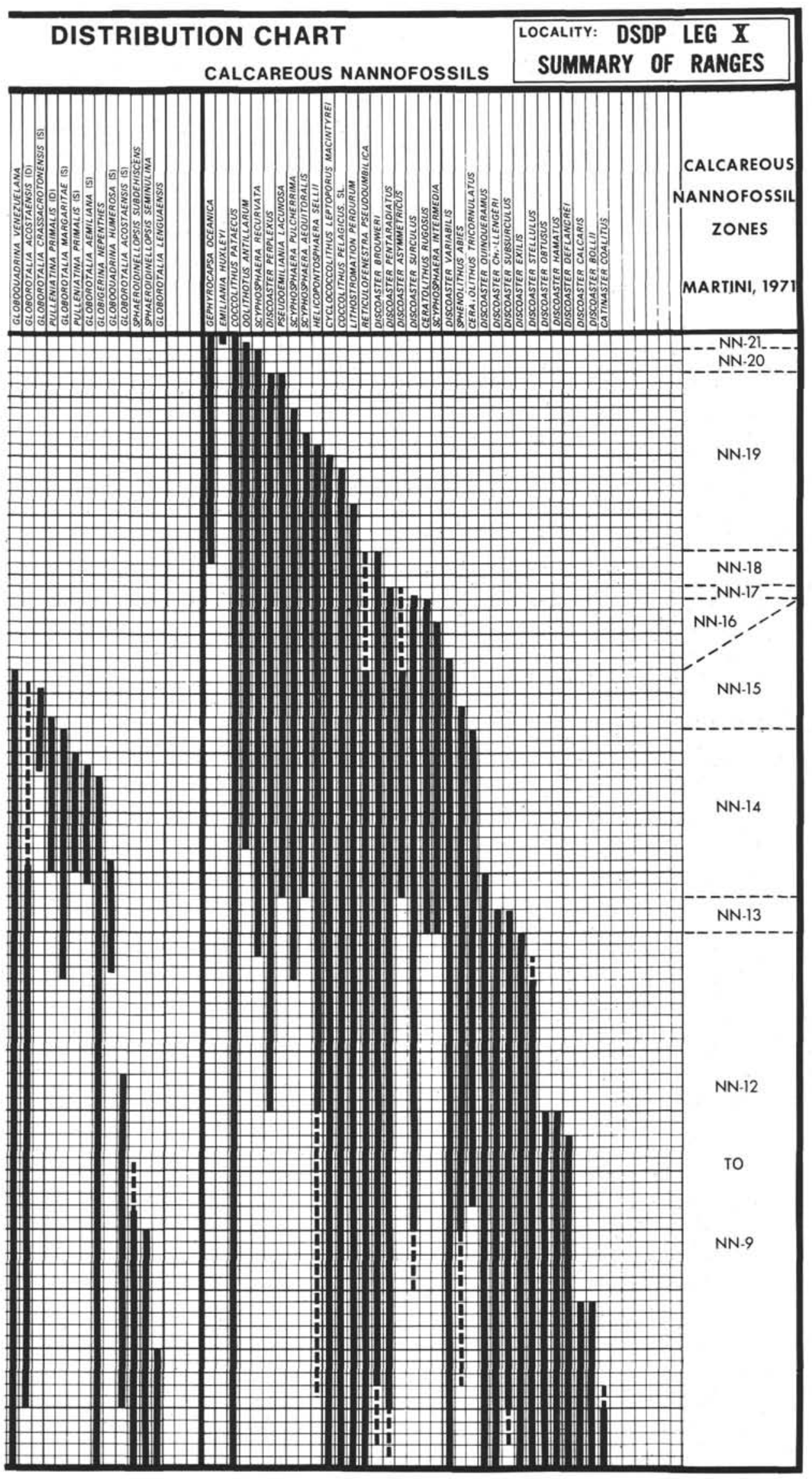

Figure 8. (Continued). 


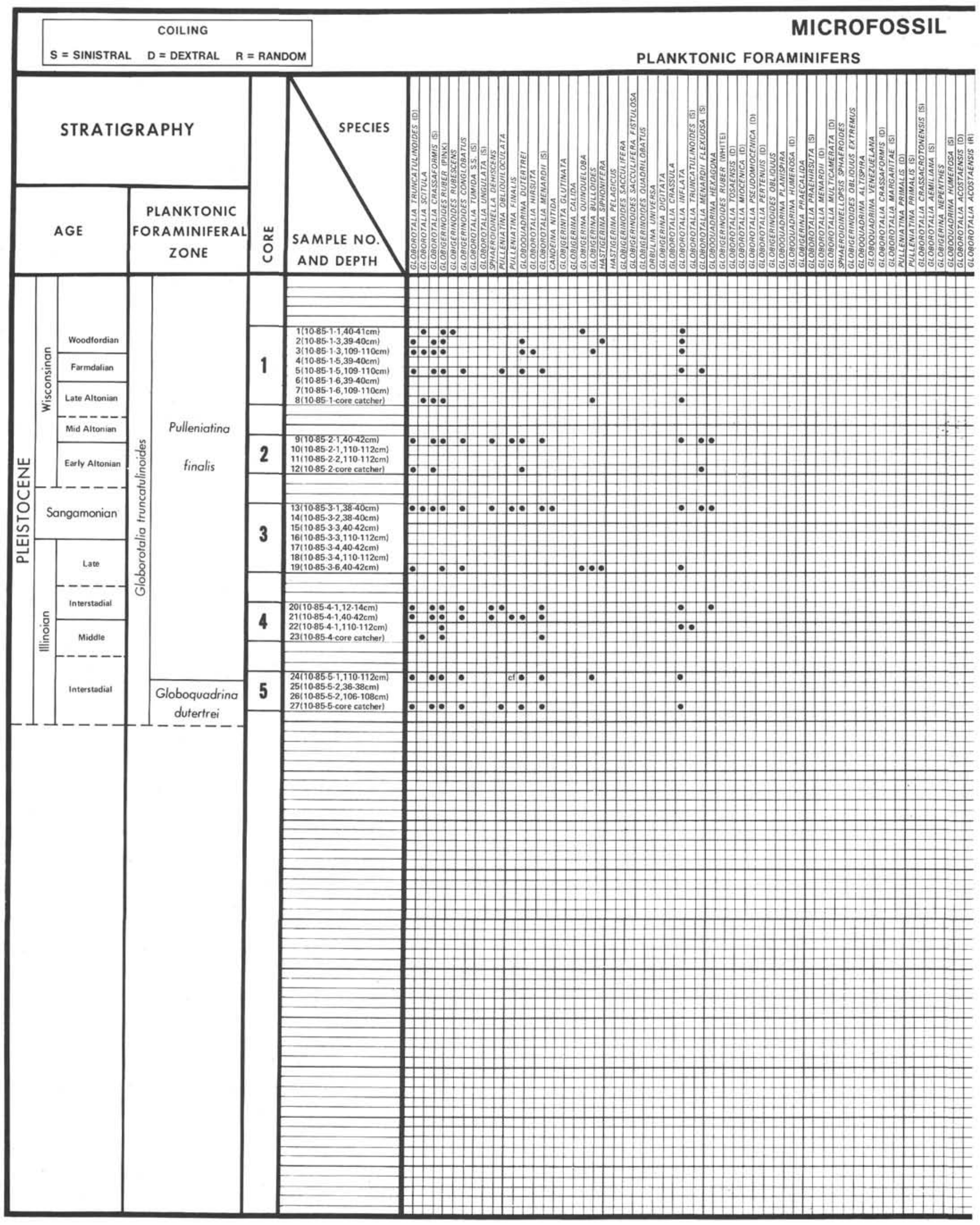

Figure 9. Microfossil distribution chart, DSDP Hole 85. 


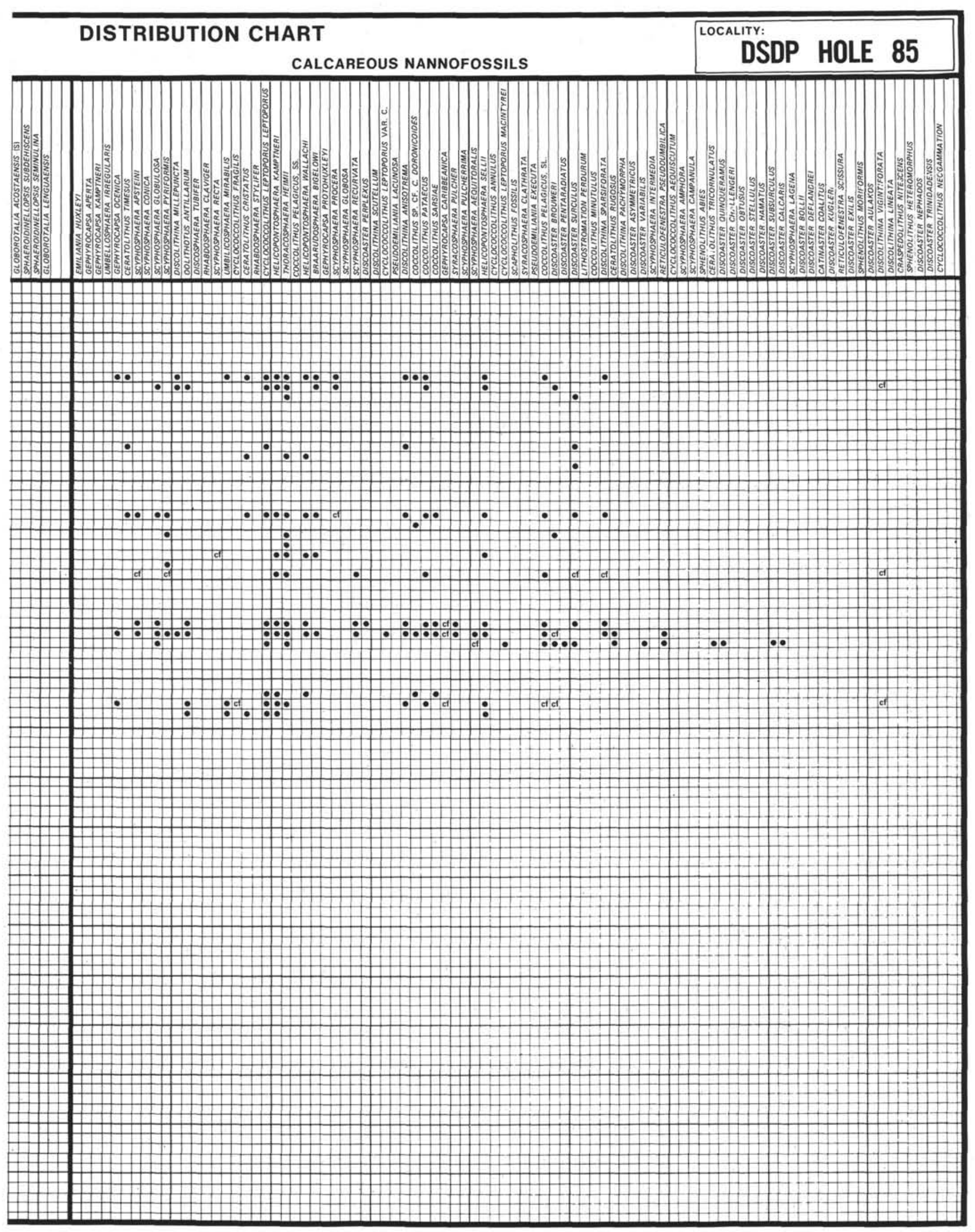

Figure 9. (Continued). 


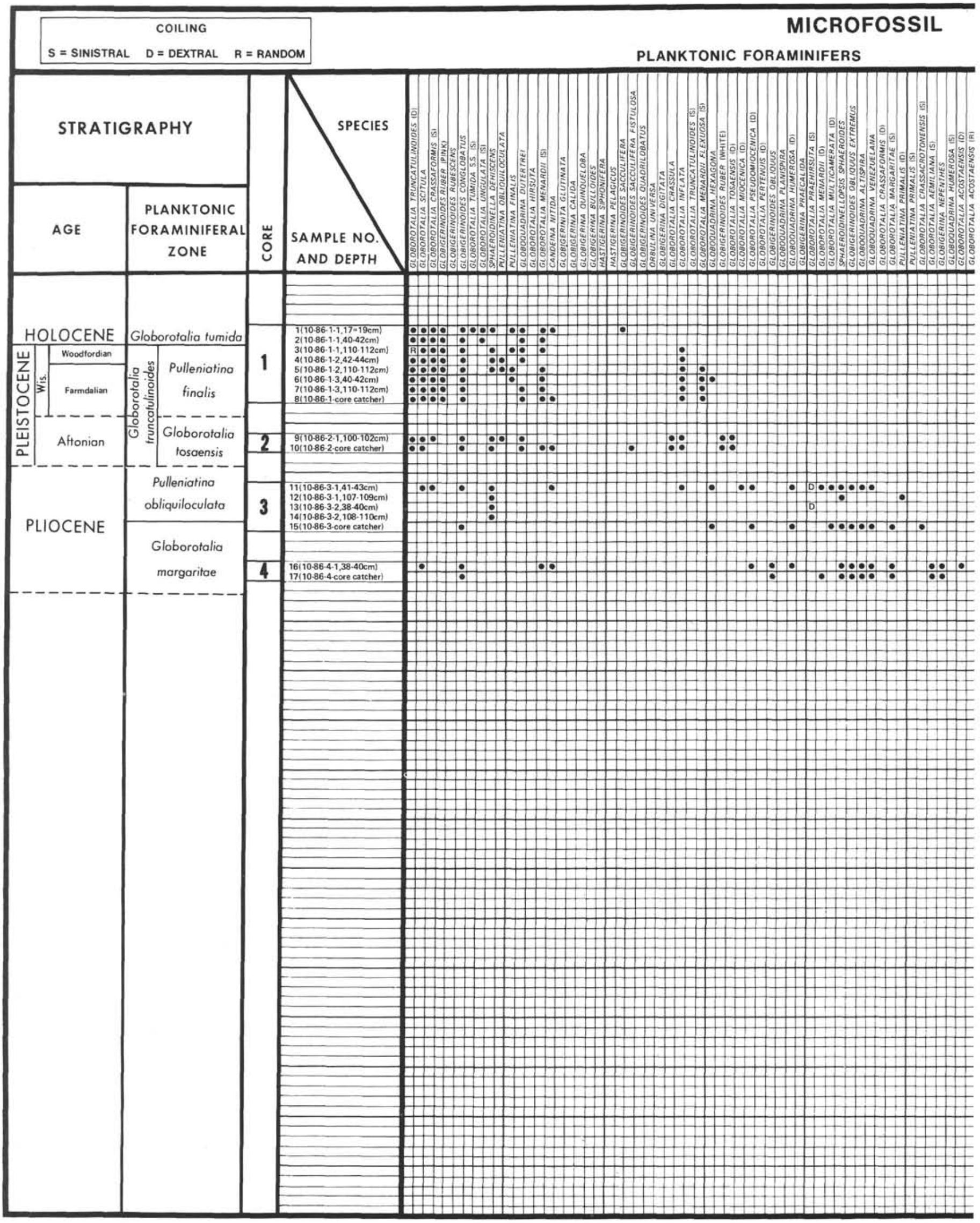

Figure 10. Microfossil distribution chart, DSDP Hole 86. 


\section{DISTRIBUTION CHART}

CALCAREOUS NANNOFOSSILS

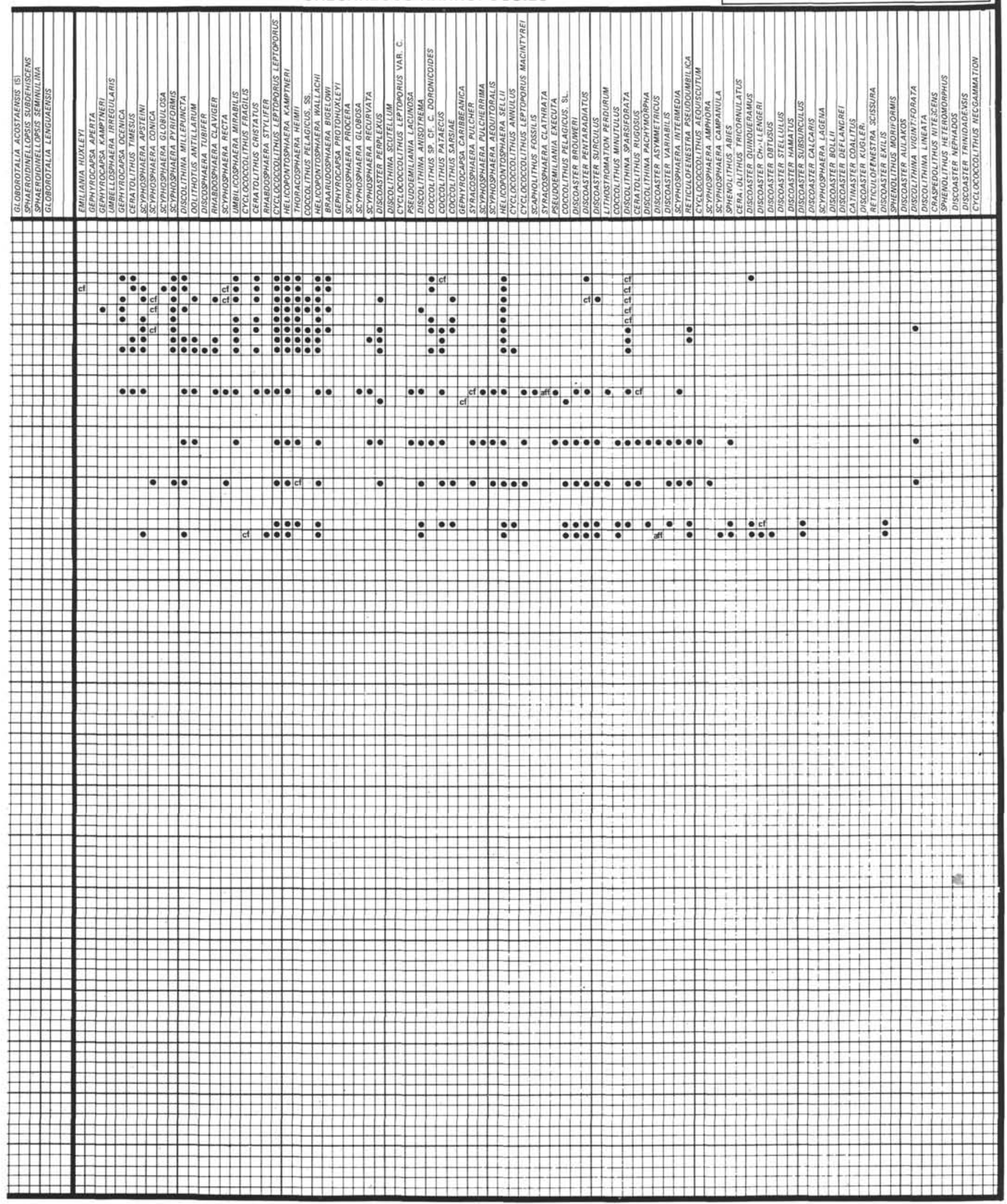

Figure 10. (Continued). 


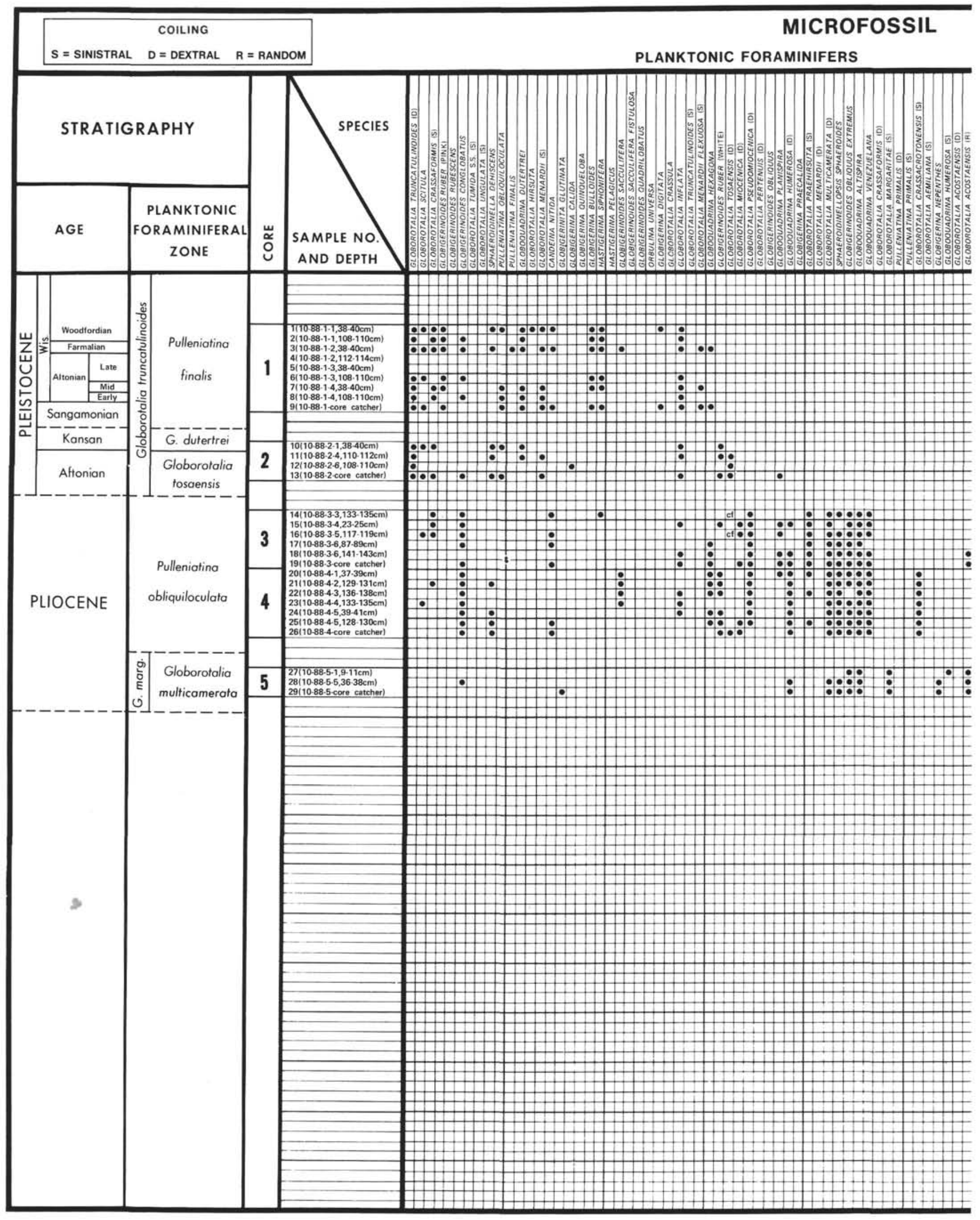

Figure 11. Microfossil distribution chart, DSDP Hole 88. 


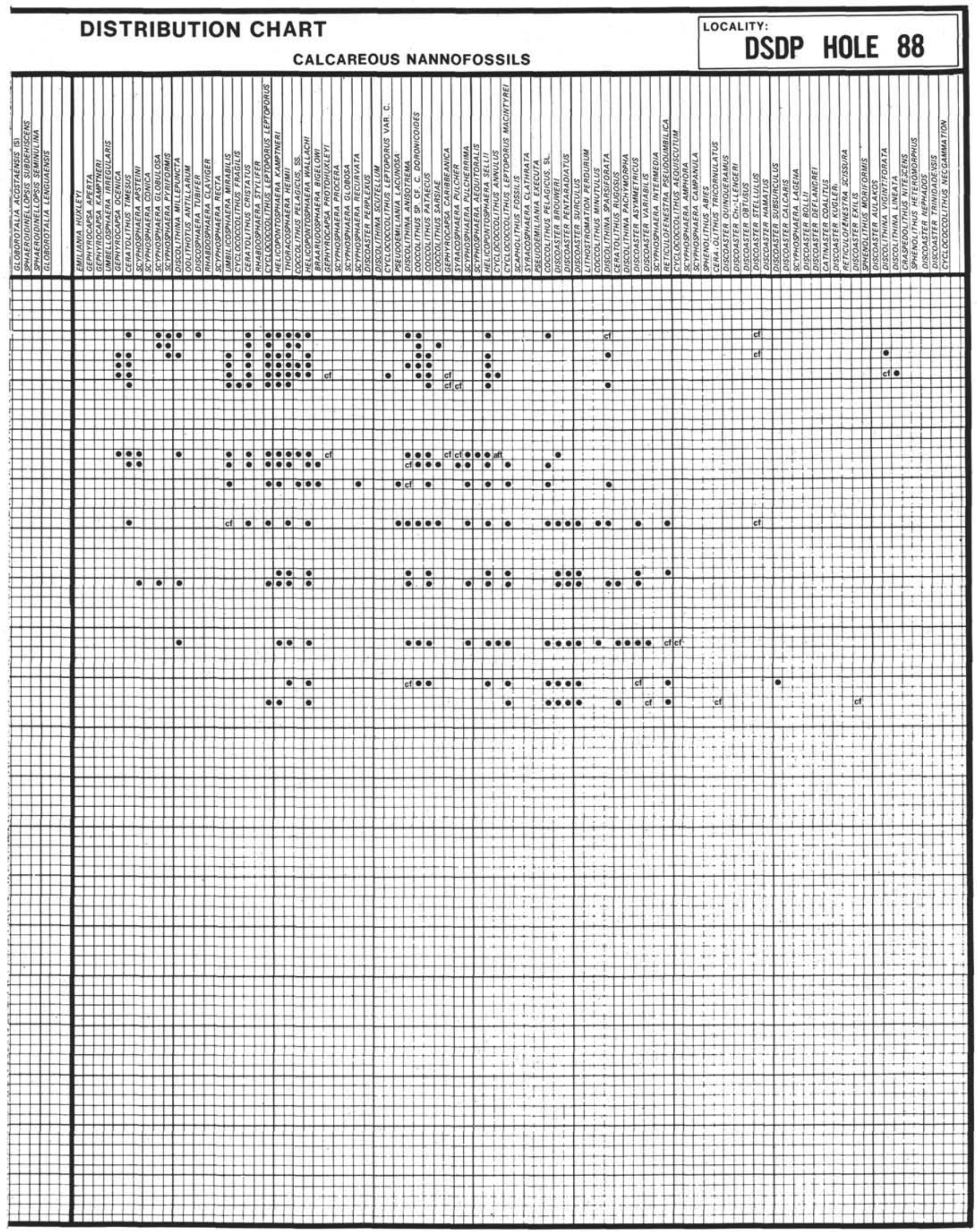

Figure 11. (Continued). 


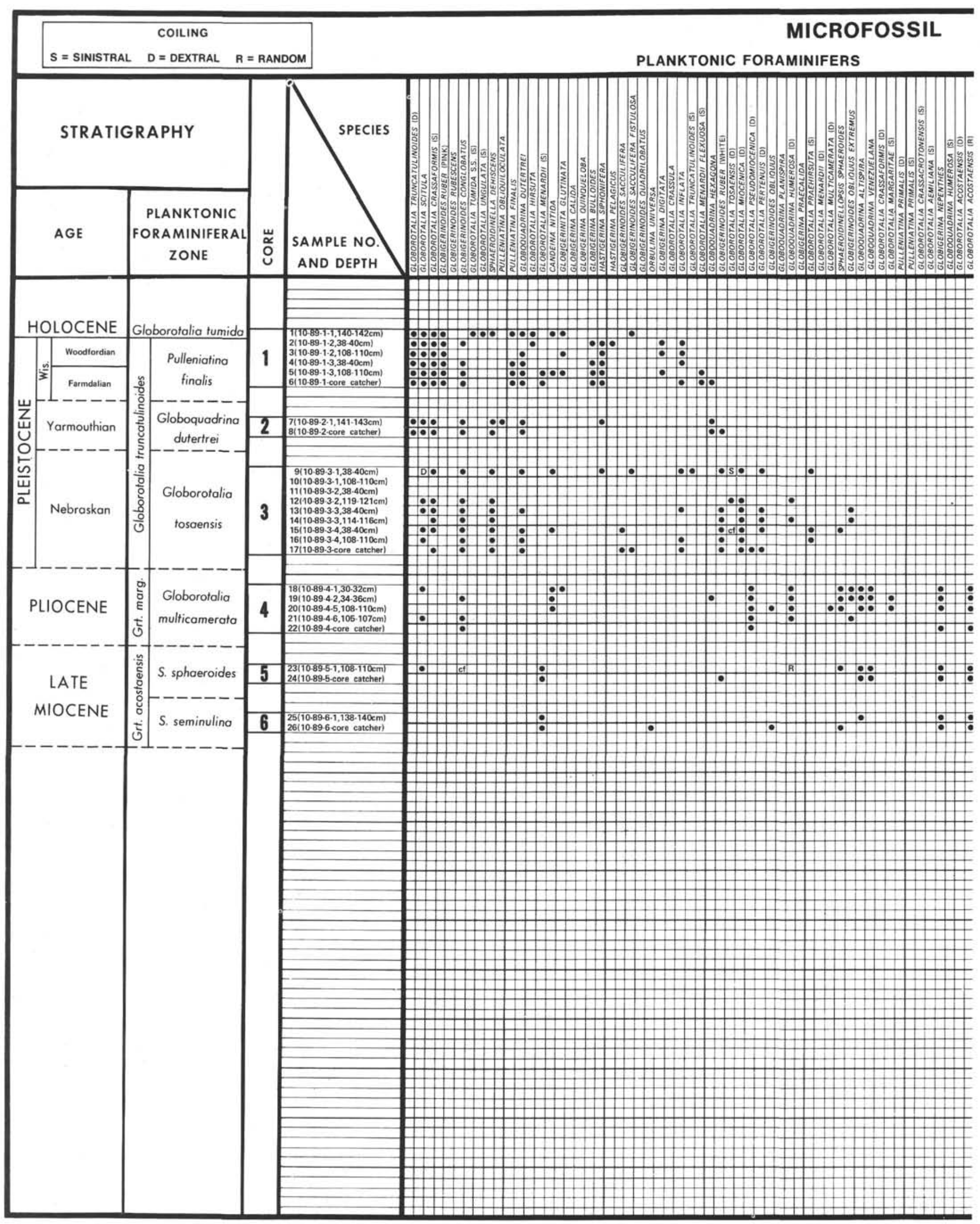

Figure 12. Microfossil distribution chart, DSDP Hole 89. 


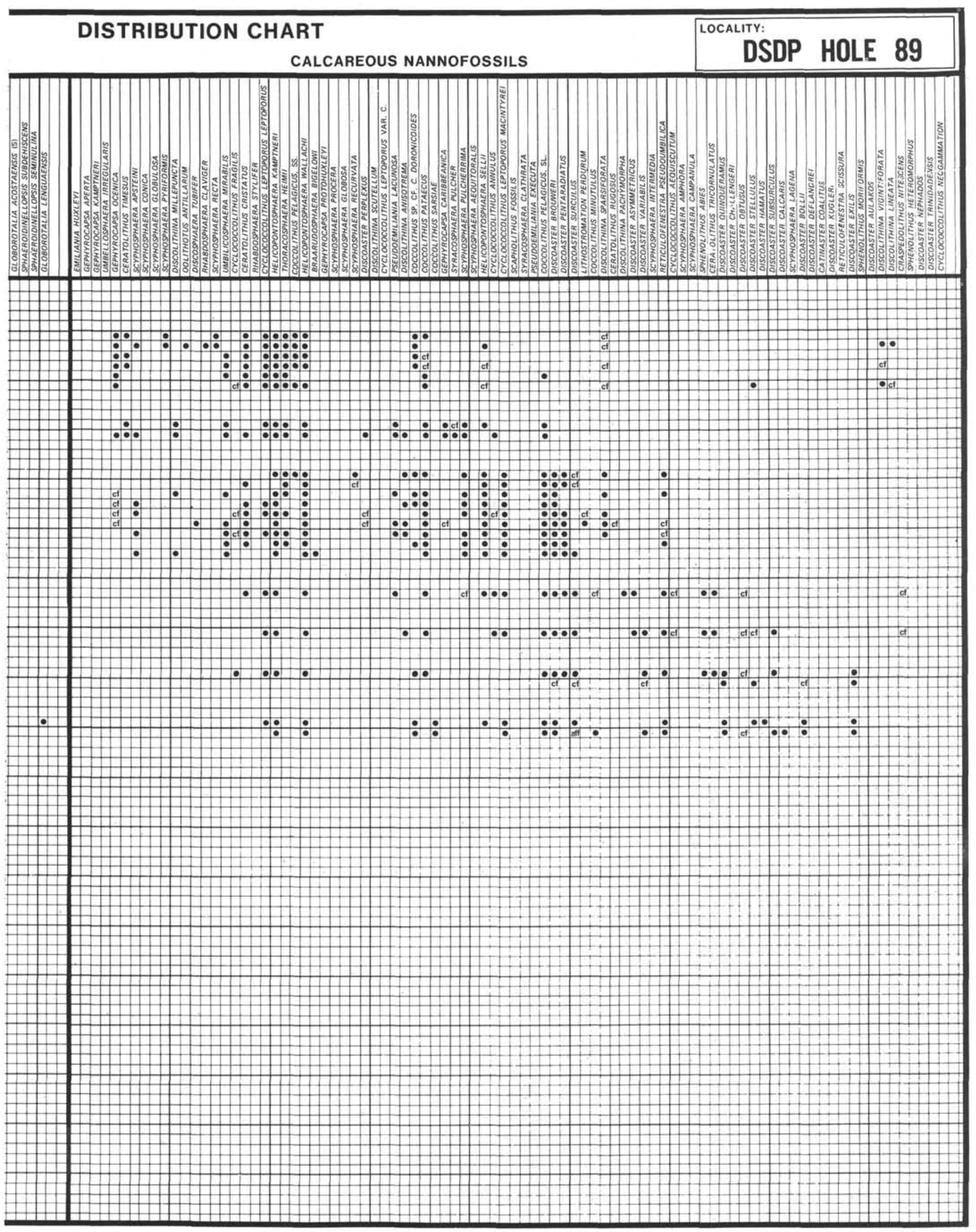

Figure 12. (Continued). 


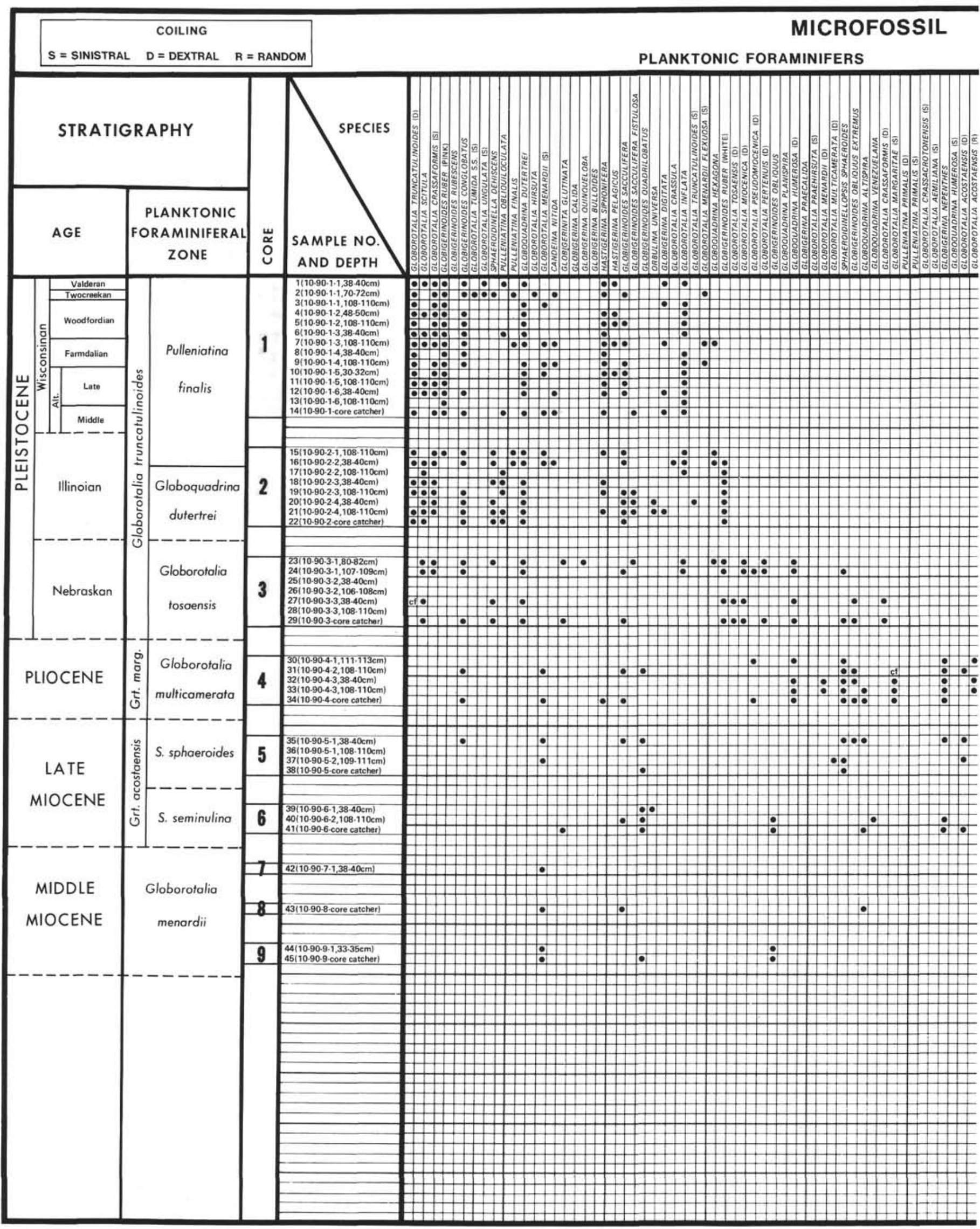

Figure 13. Microfossil distribution chart, DSDP Hole 90. 


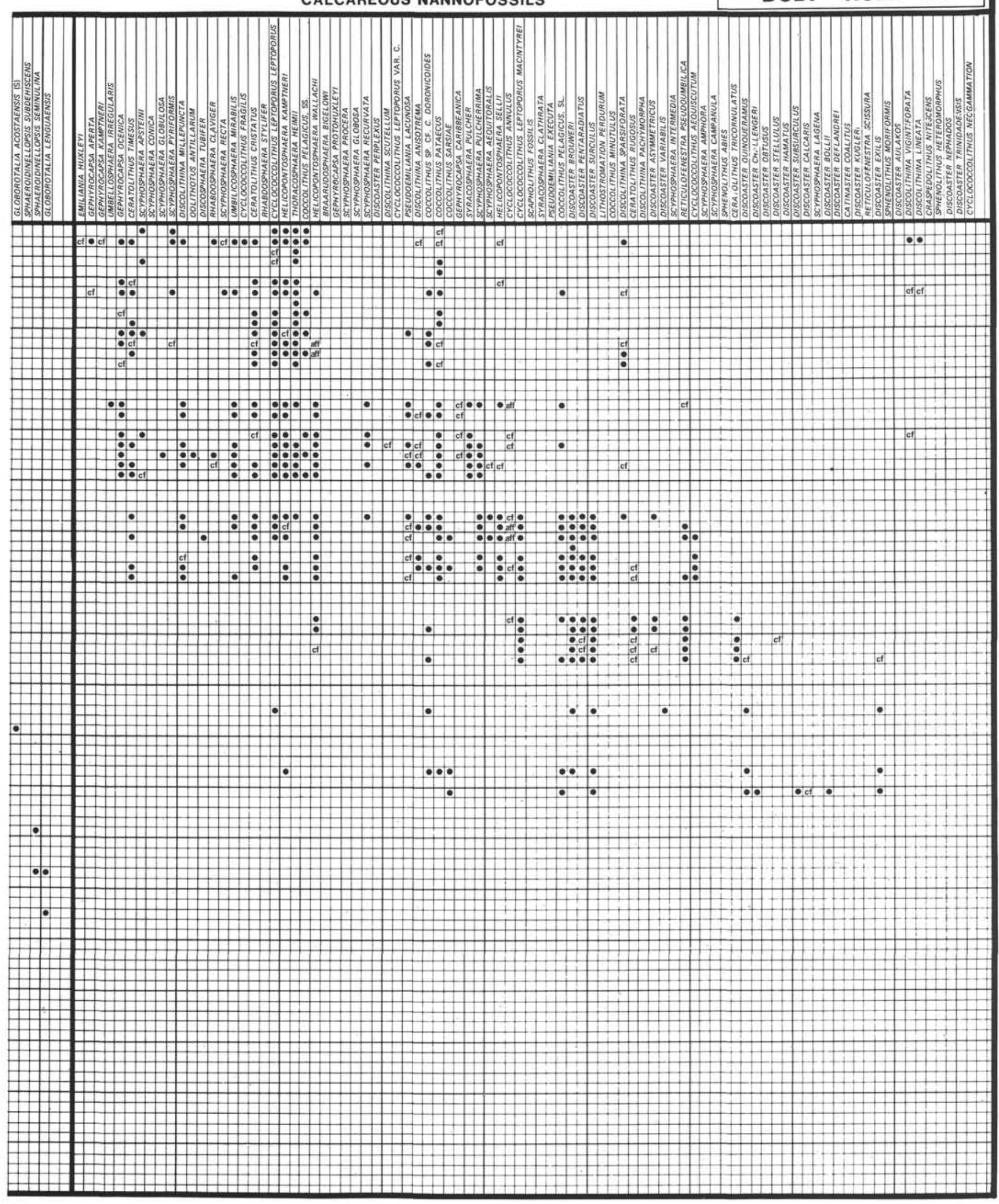

Figure 13. (Continued). 


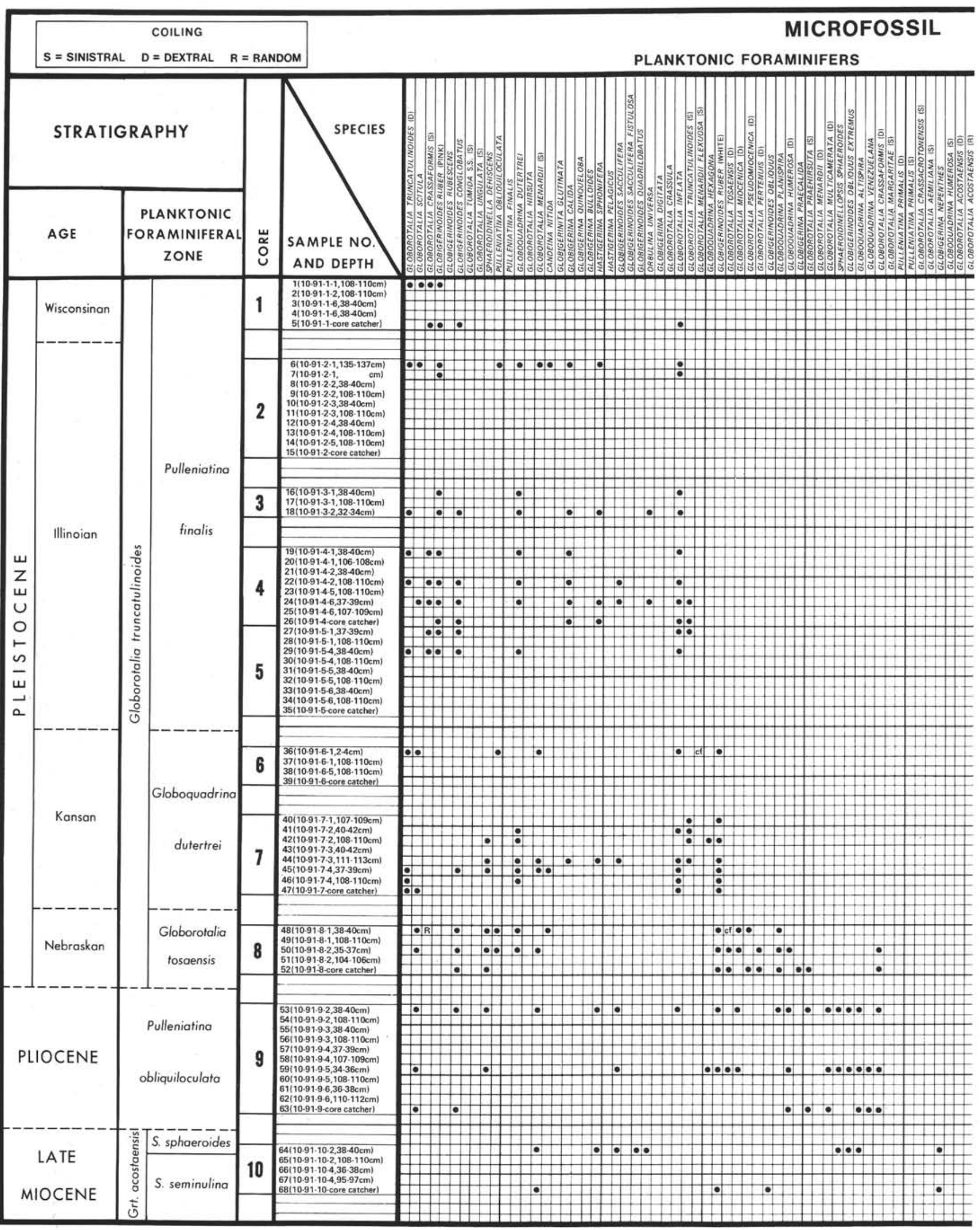

Figure 14. Microfossil distribution chart, DSDP Hole 91. 


\section{DISTRIBUTION CHART}

CALCAREOUS NANNOFOSSILS

DSDP HOLE 91

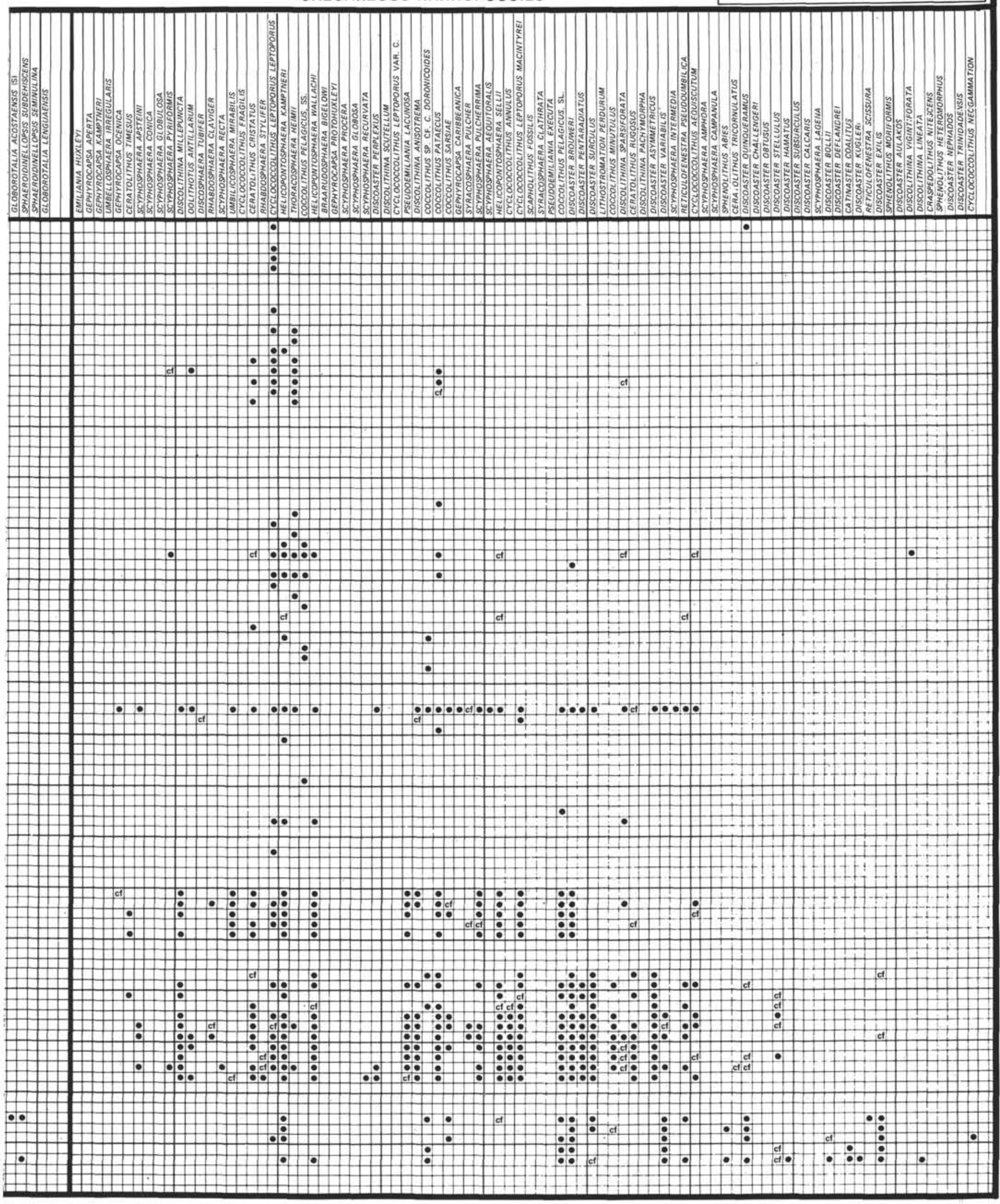

Figure 14. (Continued). 


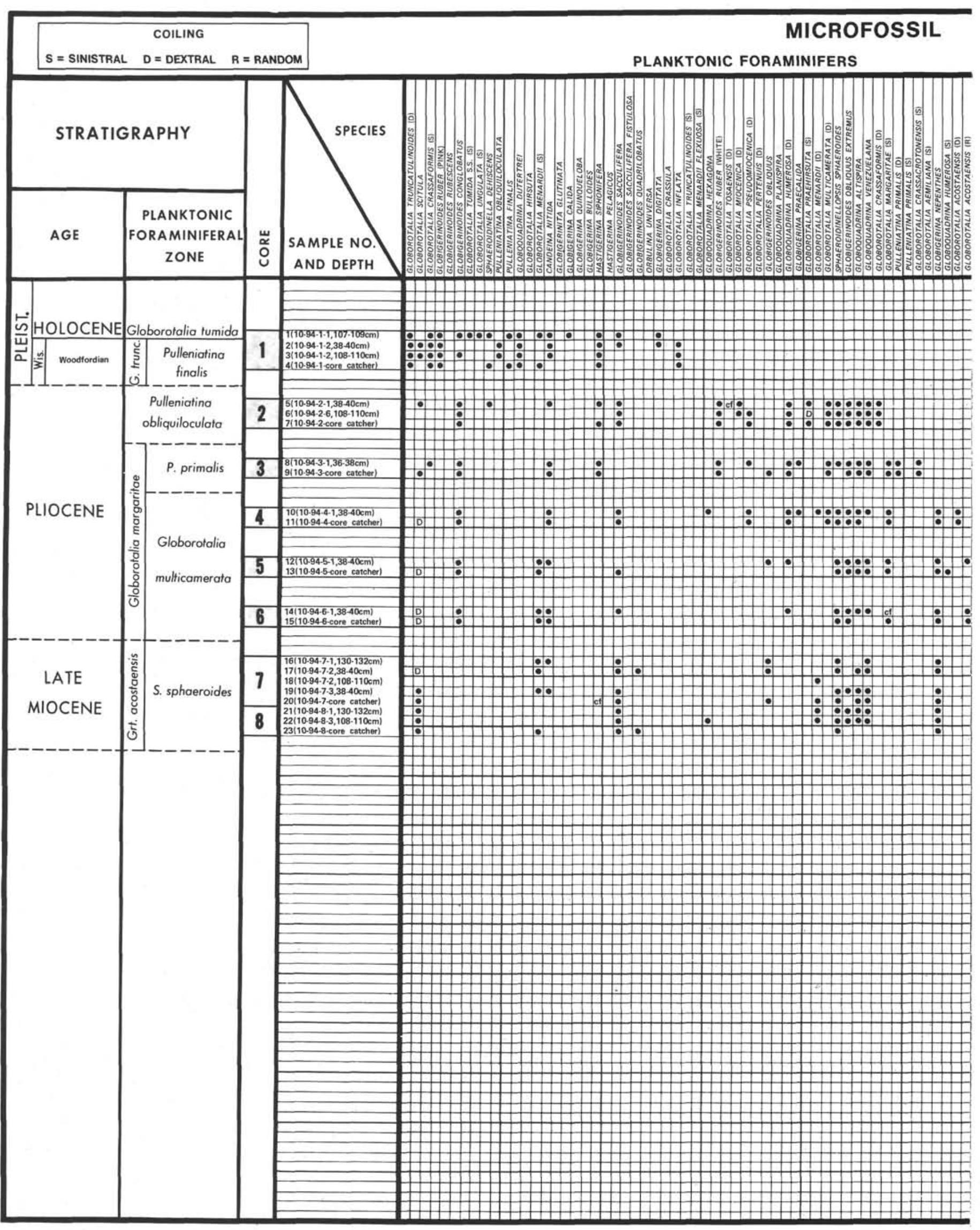

Figure 15. Microfossil distribution chart, DSDP Hole 94. 


\section{DISTRIBUTION CHART}

CALCAREOUS NANNOFOSSILS

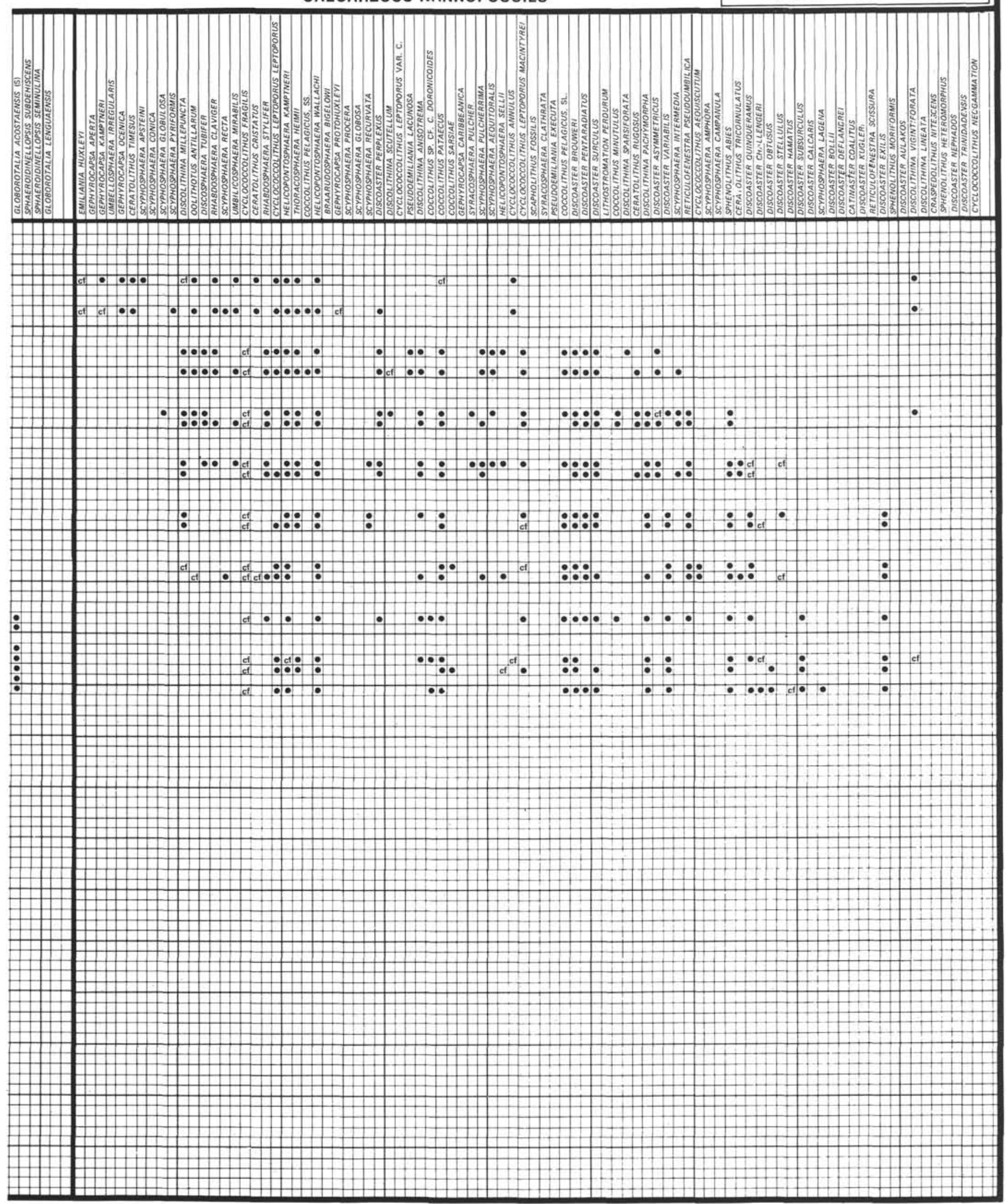

Figure 15. (Continued). 


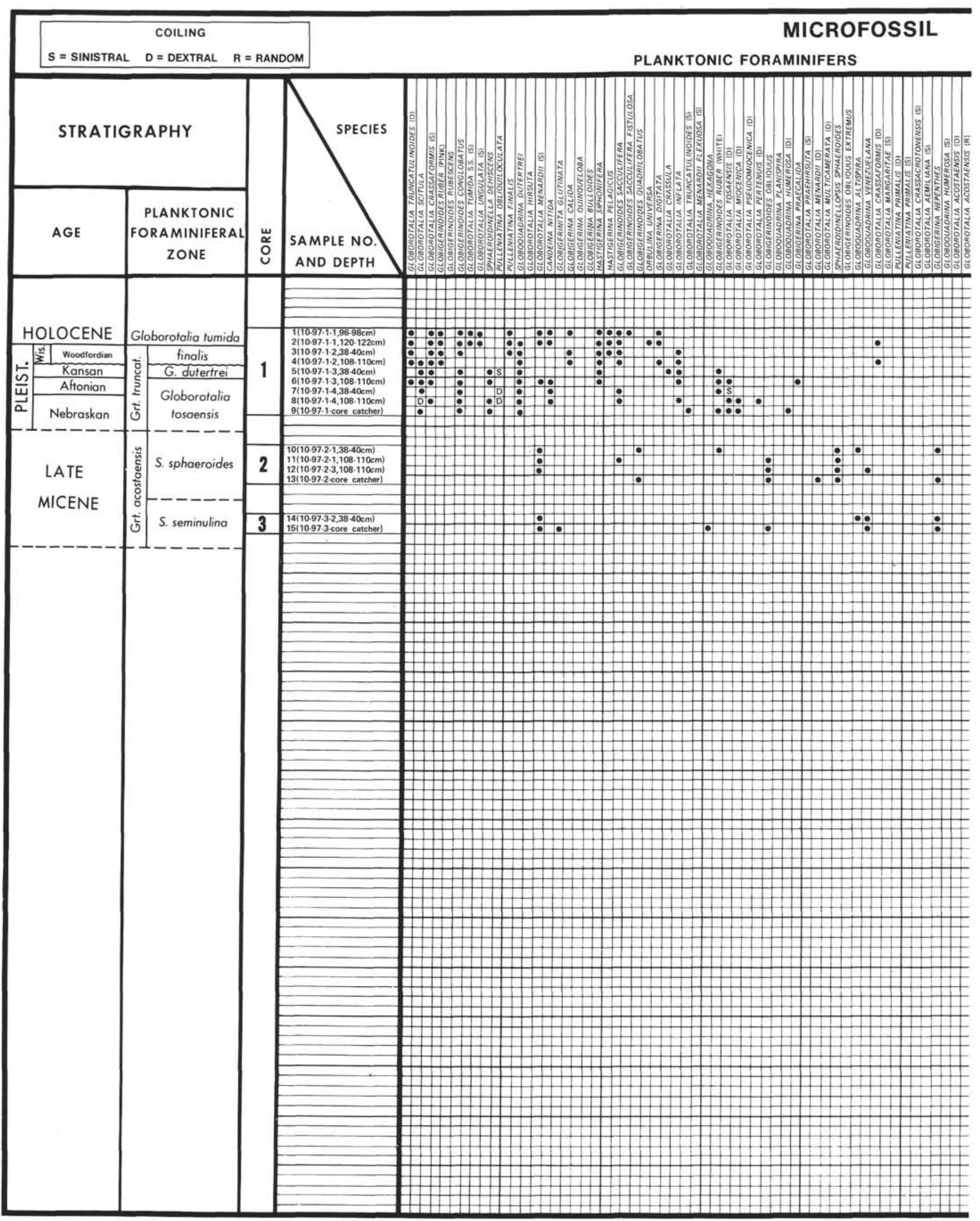

Figure 16. Microfossil distribution chart, DSDP Hole 97. 
DISTRIBUTION CHART

CALCAREOUS NANNOFOSSILS
LOCALITY:

DSDP HOLE 97

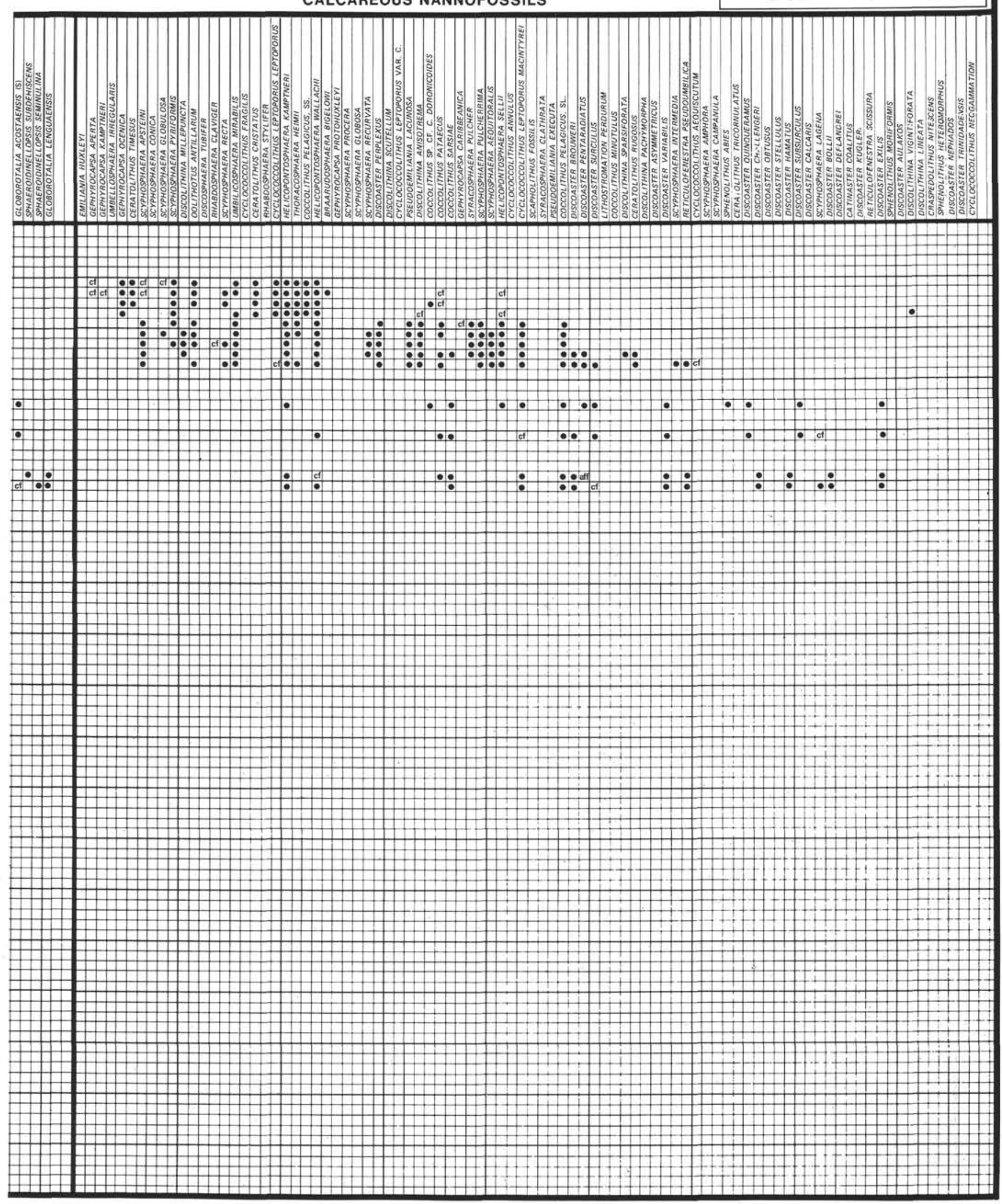

Figure 16. (Continued). 
Martini's NN-17 (the Discoaster pentaradiatus Zone of Martini and Worsley, 1970) is defined as the "interval from the last occurrence of Discoaster surculus Martini and Bramlette to the last occurrence of $D$. pentaradiatus Tan Sin Hok." These two "last occurrences" are separated by 40 to $42 \mathrm{~cm}$ in Core 1 of Hole 97. Additionally, since all of these planktonic events take place within the range of Globorotalia truncatulinoides, which first appears above the base of the stratotypical Calabrian of Italy, they occur during the Pleistocene rather than Pliocene, as suggested by many authors.

\section{ACKNOWLEDGMENTS}

Much of the review of planktonic successions in standard reference sections summarized in this paper was taken from Lamb and Beard (1972). We gratefully acknowledge the invaluable assistance of Jim Lamb in the preparation of this paper and for allowing us to draw freely from his earlier work with John Beard. We wish also to thank J. Lamar Worzel for allowing Mr. Beard's participation in the laboratory studies and Blake McNeely for relinquishing the foraminiferal work on the Late Neogene samples so as to make this team effort possible.

\section{REFERENCES}

Bandy, O. L. and Wilcoxon, J. A., 1970. The Pliocene-Pleistocene boundary, Italy and California. Bull. Geol. Soc. Am. 81, 2939.

Barbieri, F., 1967. The Foraminifera in the Pliocene section Vernasca-Castell'Arquato including the "Piacenzian stratotype" (Paicenza Province). Soc. Italiana Sci. Nat. Milano, Mem. 15. 147.

Barbieri, F. and Petrucci, F., 1967. La série stratigraphique du Messinien au Calabrien dans vallee du Crostolo (Reggio Emilia-Italie sept.). Soc. Italiana Sci. Nat. Milano, Mem. 15. 181.

Bayliss, D. D., 1969. The distribution of Hyalinea balthica (Schroeter) and Globorotalia truncatulinoides (d'Orbigny), Foraminiferida, in the type Calabrian, southern Italy. Lethaea. 2, 133.

Beard, J. H., 1969. Pleistocene paleotemperature record based on planktonic foraminifers, Gulf of Mexico. Trans. Gulf Coast Assoc. Geol. Soc. 19, 535.

, in press. Pleistocene-Holocene boundary, Wisconsinan substages, Gulf of Mexico. Geol Soc. Am. Mem. 136.

Beard, J. H. and Lamb, J. L., 1968. The lower limit of the Pliocene and Pleistocene in the Caribbean and Gulf of Mexico. Trans. Gulf Coast Assoc. Geol. Socs. 18, 174.

Berggren, W. A., 1972. Late Pliocene-Pleistocene glaciation. In Laughton, A. S., Berggren, W. A. et al., 1972. Initial Reports of the Deep Sea Drilling Project, Volume XII. Washington (U.S. Government Printing Office). 953.

Bertolino, V. et al., 1968. Proposal for a biostratigraphy of the Neogene in Italy based on planktonic foraminifera. Gior. Geol. Ser. 2. 35(2), 23.

Blow, W. H., 1959. Age, correlation, and biostratigraphy of the upper Tocuyo (San Lorenzo) and Pozón formations, eastern Falcón, Venezuela. Bull. Am. Paleontol. 39, 67. 1967. Late middle Eocene to Recent planktonic foraminiferal biostratigraphy. Proc. First Intern. Conf. Planktonic Microfossils. Geneva. 1, 199.
Blow, W. H. and Banner, F. T., 1966. Zonation of Cretaceous to Pliocene marine sediments based on planktonic foraminifera-a comment. Bol. Inf. 9, 55.

Bolli, H. M., 1957. Planktonic Foraminifera from the Oligocene-Miocene Cipero and Lengua Formations of Trinidad, B. W. I.. Bull. U. S. Natl. Museum. 215, 97. , 1966. Zonation of Cretaceous to Pliocene marine sediments based on planktonic Foraminifera. Bol. Inform. Asoc. Venez. Geol. Min. Petr. 9, 3.

Bolli, H. M. and Bermúdex, P. J., 1965. Zonation based on planktonic Foraminifera of middle Miocene to Pliocene warm-water sediments. Bol. Inform. Asoc. Venez. Geol. Min. Petr. 8, 119.

Bramlette, M. N. and Wilcoxon, J. A., 1967. Middle Tertiary calcareous nannoplankton of the Cipero section, Trinidad, W. I.. Tulane Studies Geol. 5, 93.

Cati, F. and Borsetti, A. M., 1968. Stratigrafia del Miocene marchigiano in facies di "Schlier". In G. C. Carloni, F. Cati, and A. M. Borsetti. Gior. Geol. Ser. 2. 35(2), 351.

Cati, F. et al., 1968. Biostratigraphia del Neogene mediterraneo basata sui foraminiferi planctonici. Boll. Soc. Geol. Italiana. 87, 491.

Cita, M. B. and Blow, W. H., 1969. The biostratigraphy of the Langhian, Serravallian and Tortonian stages in the type sections in Italy. Riv. Italiana Paleontol. Stratig. 75, 549.

Cita, M. B., Premoli-Silva, I. and Rossi, R. C., 1965. Foraminiferi planctonici del Tortoniano-tipo. Riv. Italiana Paleontol. Stratig. 71, 217.

Colalongo, M. L., 1968. Cenozone a foraminiferi ed ostracodi nel Pliocene e basso Pleistocene della serie del Santerno e dell'Appennino Romagnolo. Gior. Geol. Ser. 2. 35(3), 29.

Colalongo, M. L. and Sartoni, S. 1967. Globorotalia hirsuta aemiliana nuova sottospecie cronologica del Pliocene in Italia. Gior. Geol. Ser. 2. 34, 255.

Committee on Mediterranean Neogene Stratigraphy, 1967. Excursion guidebooks 1 and 2. R. Selli (Ed.). Intern. Union Geol. Sci., 4th Intern. Cong. Bologna, Italy.

Crescenti, U. 1966. Sulla biostratigrafia del miocene affiorante al confine marchigianoabruzzese. Geol. Romana. 5, 1.

Dallan, L. and Salvatorini, G., 1968. Biostratigrafia del Pliocene della Toscana marittima. Soc. Toscana Sci. Nat. Atti. Mem., Ser. A. 74, 570.

Dondi, L. and Papetti, I., 1968 [1969]. Biostratigraphical zones of Po Valley Pliocene. Gior. Geol. Ser. 2. 35,(3), 63.

d'Onofrio, S. 1964. I Foraminiferi del neostratotipo del Messiniano. Gior. Geol. Ser. 2. 32, 409.

. 1968 [1969]. Biostratigrafia del Pliocene e Pleistocene inferiore nelle Marche. Gior. Geol. Ser. 2. 35, 99.

Emiliani, C., 1971. Paleotemperature variations across the Plio-Pleistocene boundary. Science. 171, 60.

Emiliani, C., Mayeda, T. and Selli, R., 1961. Paleotemperature analysis of the Plio-Pleistocene section at LeCastella, Calabria, southern Italy. Bull. Geol. Soc. Am. 72, 679.

Follador, U., 1967. Il Pliocene ed il Pleistocene dell'Italia centromeridionale, versanta adriatico, biostratigrafia. Boll. Soc. Geol. Italiana. 86, 565.

Gartner, S., 1969. Correlation of Neogene planktonic foraminifer and calcareous nannoplankton zones. Trans. Gulf Coast Assoc. Geol. Soc., 19, 585. 
Gianotti, A., 1953. Microfaune della serie Tortoniana del Rio Mazzapiedi-Castellania (Tortona-Alessandria). Riv. Italian Paleontol. Stratig. Mem. 6. 167.

Gignoux, M., 1913. Les formations marines pliocenes et quaternaires de l'Italie du Sud et de la Sicile. Ann. Lyon Univ. N. S. 35, 693.

Gradstein, F. M., 1970. Foraminifera from the type Sicilian at Ficarazzi, Sicily (lower Pleistocene). Koninkl. Ned. Akad. Wetenschap. Proc., Ser. B. 73(4), 1.

Hay, W. W. et al., 1967. Calcareous nannoplankton zonation of the Cenozoic of the Gulf Coast and Caribbean-Antillean area, and transoceanic correlation. Trans. Gulf Coast Assoc. Geol. Soc. 17, 428

Hays, J. D. et al., 1969. Pliocene-Pleistocene sediments of the equatorial Pacific: their paleomagnetic, biostratigraph, and climatic record. Bull. Geol. Soc. Am. 80,1481 .

Iaccarino, S., 1967. Les foraminiféres du stratotype du Batianien (Pliocene inférieur) de Tabiano Bagni (Parme). Soc. Italiana Sci. Nat. Milano, Mem. 15. 165.

International Geological Congress, 1950. Recommendations of commission appointed to advise on the definition of the Pliocene-Pleistocene boundary. Proc. Intern. Geol. Congr., 18th, London. Sect. H, Pt. 9, 6 .

Jenkins, D. G., 1967. Planktonic foraminiferal zones and new taxa from the Pleistocene of New Zealand. New Zealand J. Geol. Geophys. 10, 1064.

Lamb, J. L., 1969. Planktonic foraminiferal datums and late Neogene epoch boundaries in the Mediterranean, Caribbean, and Gulf of Mexico. Trans. Gulf Coast Assoc. Geol. Soc. 19, 559.

, 1971. Planktonic foraminiferal biostratigraphy and paleomagnetics of Late Pliocene and Early Pleistocene strata at LeCastella, Italy. Trans. Gulf Coast Assoc. Geol. Soc. 21,411 .

Lamb, J. L. and Beard, J. H., 1972. Late Neogene planktonic foraminifers in the Caribbean, Gulf of Mexico, and Italian stratotypes. Univ. Kansas Press. Univ. Kansas Paleo. Contrib., Art. 57 (Prot. 8), 67 p.

Martini, E., 1969. Nannoplankton aus dem Miozän von Gabon (Westafrika). Neues Jahrb. Geol. Paläont. Abh. $132,285$.

1970. Standard Palaeogene calcareous nannoplankton zonation. Nature. 226, 560.

, 1971. Standard Tertiary and Quaternary calcar eous nannoplankton zonation. Proc. 2nd Plankt. Conf. Roma. 2, 739.
Martini, E. and Worsley, T. R., 1970. Standard Neogene calcareous nannoplankton zonation. Nature. 225, 289.

Mayer-Eymar, C., 1858. Versuch einer synchronistischen Tabelle der Tertiär-Gebilde Europas. Schweizer. Naturf. Verh., Trogen.

1868. Tableau synchronistique des terrains tertiaires supérieurs. Zurich.

McIntyre, A., Bé, A. and Preikstas, R., 1967. Coccoliths and the Pliocene-Pleistocene boundary. In Sears, M. (Ed.), Progress in Oceanography, Vol. 4. The Quaternary History of the Ocean Basins. New York (Pergamon Press). 3.

Nakagawa, H., Niitsuma, N. and Elmi, C., 1971. Pliocene and Pleistocene magnetic stratigraphy in LeCastella area, southern Italy-a preliminary report. Quaternary Res. $1(3), 360$.

Ogniben, Leo, 1962. Le argille scagliose ed i sedimenti messiniani a sinistra del Trionto (Rossano, Cosenza). Geol. Romana. 1, 257.

Pezzani, F., 1963. Studio micropaleontologico di un campione della serie messiniana di Tabiano Bagni (Parma). Riv. Italiana Paleontol. Stratig. 69, 559.

Ruggieri, G., 1965. A contribution to the stratigraphy of the marine lower Quaternary sequence in Italy. Geol. Soc. Am. Spec. Paper 84. 141.

Selli, R., 1960. Il Messiniano Mayer-Eymar 1867; proposta di un neostratotipo. Gior. Geol. Ser. 2. 28, 1. 1967a. Calabrian. In Studies on the Stratotypes. Intern. Union. Geol. Sci., Committee on Meditteranean Neogene Stratigraphy. 30. , 1967b. The Pliocene-Pleistocene boundary in Italian marine sections and its relationship to continental stratigraphies. In Sears, M. (Ed.), Progress in Oceanography, Vol. 4. The Quaternary History of the Ocean Basins. New York (Pergamon Press). 67.

Smith, L. A., 1965. Paleoenvironmental variation curves and paleoeustatics. Trans. Gulf Coast Assoc. Geol. Soc. $15,47$.

1969. Pleistocene discoasters from the stratotype of the Calabrian Stage (Santa Maria di Catanzaro) and the section at Le Castella, Italy. Trans. Gulf Coast Assoc. Geol. Soc. 19, 579.

Stainforth, R. M., 1948. Description, correlation and paleoecology of Tertiary Cipero Marl Formation, Trinidad, B. W. I. Bull. Am. Assoc. Petrol. Geologists. 32, 1292.

Wezel, F. C., 1968 [1969]. Le cenozone del Pliocene superiore-Pleistocene inferiore in Sicilia e Lucania. Gior. Geol. 35(3), 437. 